Iury Tércio Simões de Sousa

\title{
Recurrent anticyclone formation and shedding within the Barreirinhas Bight (NE-Brazil)
}

\begin{abstract}
A thesis submitted in partial fulfillment of the requirements for the degree of Master of Sciences in Oceanography, with emphasis in Physical Oceanography, Instituto Oceanográfico, Universidade de São Paulo.
\end{abstract}

Advisor: Prof. Dr. Ilson Carlos Almeida da Silveira.

São Paulo

2017 


\title{
Universidade de São Paulo Instituto Oceanográfico
}

\section{Recurrent anticyclone formation and shedding within the Barreirinhas Bight (NE-Brazil)}

\author{
by \\ Iury Tércio Simões de Sousa
}

A thesis submitted in partial fulfillment of the requirements for the degree of Master of Sciences in Oceanography, with emphasis in Physical Oceanography, Instituto Oceanográfico, Universidade de São Paulo.

Evaluated in I 

"Se eu soubesse que tinha mandado um burro fazer isso, ia eu mesmo!"

Seu Madruga 


\section{Acknowledgements}

This is one of the difficult part to write. I don't know how and where I should begin. I just know that is hard to put in words at 1 o'clock in the morning when I am still in the lab doing my job. That's it, the scientist job is not a question of how much you earn but how much you are curious about the world that you live. I am here because I am a result of love and dedication of my family, mainly my parents Sandra and Vicente. I am your fan, and this is for you too. You that teach me that being haemophilic is just a condition, not a limit to do whatever I dream to. I really have to thank my brothers Igor, and specially, Diego. We're being closer nowadays and that's incredible for thousands-distant two people. I know that you are here for me.

I cannot forget to thank my friend and advisor Ilson. You believed in me even when I thought that impossible and helped me until the last second. I learned a lot being here at LaDO and I know that we will keep this friendship through the years. The major part of being a Oceanographer I learned with you and I still want to learn it.

I'd like to thank professor and mentor Carlos Teixeira. You gave me the insight that turned to all this dissertation.

I have to thank professors Belmiro Castro, Paulo Polito and Olga Sato for their precious teaching. It was a pleasure being your student.

I'd like to thank Nancy Kazumi, and Patrícia Baldasso who helped me from the simple to a huge problems in a important part of this trajectory.

I cannot forget to thank professor Glenn Flierl for his insights. I can't believe that I had the opportunity to discuss my work with you.

It's important to thank André Paloczy, Tiago Biló and professor Wandrey Watanabe for all the crucial contributions.

A special thank to my portuguese brother, Helio. A great friend and scientist that I had the pleasure to meet. We laughed and wept many times with the pleasures and despairs that live away from our land can bring to us. 
I'd like to thank Dante for teach me to lead with the difficulties and differences easy, because we will always find a way to laugh of everything.

I didn't forget you, Renata. I know that we are not so close now, but it all had a begin a long time ago, when you took care of me even when I lost my head. I will always remember you fondly.

A special thank to my São Paulo friends Ana Losnak, Liane, Pedro Guillaumon, Eduardo Dobay, Débora Ito, Juliana Santos, Matheus Cortezi, Ana Paula Loureiro and Aline Santana. So different phases, so different places, and you all make the difference to feel like home to me.

I would like to thank to my friends in Fortaleza, Bruno Gonçalves, Igor Uchôa, Matheus Carrion, Camena Costa, Raquel Catunda and Thiago Parente. Despite the distance, its always great to have a time with you.

It is inexcusable to forget to thank Ágata. It was crazy to live in this huge city and you're part of my family here. You are always ready to help and listen me. Thank you for being such a beautiful person and make my days so happy and interesting.

Finally, I really have to thank to FAPESP for believe and founding this project. I want to thank the Petróleo Brasileiro SA (PETROBRAS) too, specially Renato Parkinson, and the Diretoria de Hidrografia e Navegação (DHN) from the Brazil's Navy for providing all the observational data used in this work. 


\section{Contents}

Page

List of Figures $\quad x i$

$\begin{array}{lc}\text { List of Tables } & \text { xii }\end{array}$

$\begin{array}{lc}\text { List of Acronyms } & \text { xiii }\end{array}$

$\begin{array}{ll}\text { Abstract } & \text { xiv }\end{array}$

Resumo $\quad$ xvi

1 Introduction 1

1.1 The North Brazil Current Recent History $\ldots \ldots \ldots \ldots \ldots \ldots$

1.2 Layered current patterns . . . . . . . . . . . . . . . . . 6

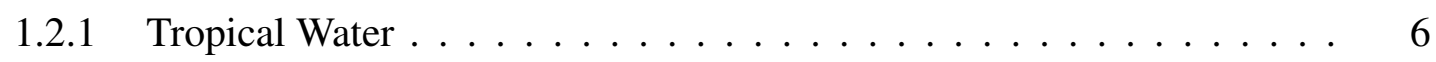

1.2.2 South Atlantic Central Water . . . . . . . . . . . . . . . . . 6

1.2.3 Antarctic Intermediate Water . . . . . . . . . . . . . . . 7

1.3 Seasonal and Intraseasonal Variability $\ldots \ldots \ldots \ldots \ldots \ldots \ldots$

1.4 The Potiguar Bight $\ldots \ldots \ldots \ldots \ldots \ldots \ldots$

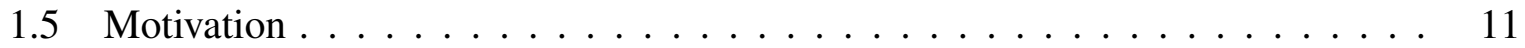

1.6 Scientific Hypotheses and Questions . . . . . . . . . . . . . . . . 12

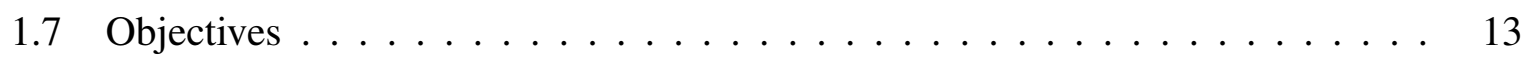

2 Datasets 14

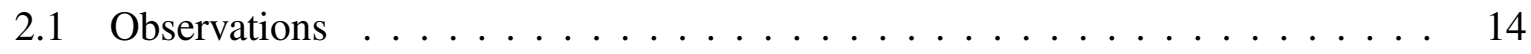

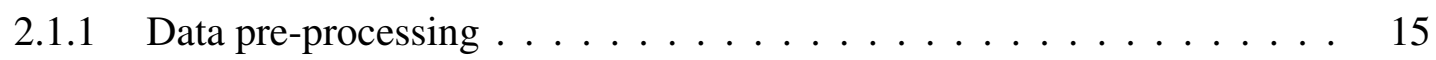


2.2 Global HYCOM Experiment $19.1 \ldots \ldots \ldots$

3 Analysis of the Observational Data 19

3.1 The ON1 Quasi-synoptic Data Set . . . . . . . . . . . . . . . . . . . . 19

3.1.1 Deformation Radius Calculation . . . . . . . . . . . . . . . . . . 19

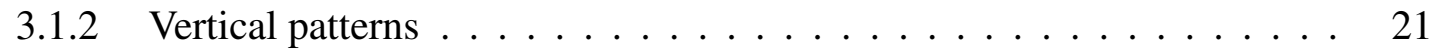

3.1 .3 Horizontal patterns $\ldots \ldots \ldots \ldots \ldots \ldots$

3.1.4 Dimensionless Numbers . . . . . . . . . . . . . . . 26

3.2 The PETROBRAS BAR1 Mooring . . . . . . . . . . . . . . . 27

3.2.1 Mean Profile and Time Series Description . . . . . . . . . . . . . 28

3.2 .2 Event statistics . . . . . . . . . . . . . . . . . . . 29

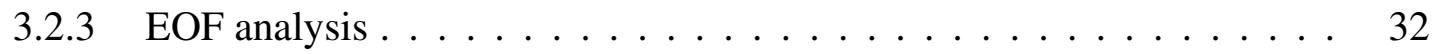

4 Analysis of the HYCOM Output 39

4.1 Model Output Confirmation . . . . . . . . . . . . . . . . . . . . . . . 40

4.1.1 The Synthetic Velocity Transects . . . . . . . . . . . . . . . 40

4.1.2 The Synthetic Mooring Line . . . . . . . . . . . . . . . . . . 41

4.2 The HYCOM Mean Fields . . . . . . . . . . . . . . . . . . . 45

4.3 The Barreirinhas Eddy Cycle . . . . . . . . . . . . . . . . 48

4.3 .1 The Near-surface Eddy . . . . . . . . . . . . . . . . . . . . 49

4.3 .2 The Pycnoclinic Eddy . . . . . . . . . . . . . . . . 50

4.3 .3 The Eddy Composite . . . . . . . . . . . . . . . . . . 52

4.4 Summary and Discussion $\ldots \ldots \ldots \ldots \ldots \ldots$

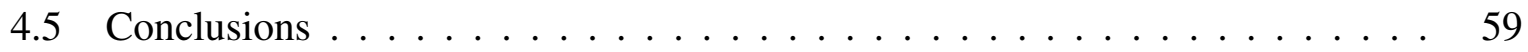

4.6 Future Work . . . . . . . . . . . . . . . . . . . . . 60

$\begin{array}{ll}\text { Bibliography } & 64\end{array}$ 


\section{List of Figures}

1.1 The North Brazil Undercurrent velocity distribution versus offshelf distance at $5.5^{\circ} \mathrm{S}$ and $10^{\circ} \mathrm{S}$ in November 1992 from the lowered-ADCP rotated to show the along-shore component. From Stramma et al. (1995). . . . . . . . . . . . . . . . 2

1.2 Upper panel: 3D scheme representing the NBUC formation in 3 different layers. Only the northward flow for each SEC bifurcation is presented. Lower panel: Scheme representing the NBUC's formation and transformation in different latitudes. TW: Tropical Water from the surface to the $\sigma_{0}=24.5$ isopycnal surface, SACW: South Atlantic Central Water from $\sigma_{0}=24.5$ to the $\sigma_{0}=26.8$ isopycnal surfaces, AIW: Antartic Intermediate Water from $\sigma_{0}=26.8$ to the $\sigma_{1}=32.15$ isopycnal surfaces. Adapted by Soutelino et al. (2013). . . . . . . . . . . . . . .

1.3 The April 1983 alongshore velocity section off Cape Frio $\left(23^{\circ} \mathrm{S}\right)$. Positive velocities are northeastward. Contour intervals are $0.05 \mathrm{~m} \mathrm{~s}^{-1}$. The red contour identify the IWBC lobe. Adapted from Da Silveira et al. (2004). . . . . . . . . .

1.4 The surface current field including (left) geostrophic component, (middle) Ekman drift component and (right) total (i.e., sum of fields in left and middle panels). Velocity vectors are in centimeters per second. From Silveira et al. (1994)

1.5 Vertical sections of the eastward component of speed $\left(\mathrm{m} \mathrm{s}^{-1}\right)$ for $41^{\circ} \mathrm{W}$ transect. The 24.5 and 26.8 isopycnal surfaces and transport of the major currents are also given. NBC, North Brazil Current, SEC, South Equatorial Current, NECC, North Equatorial Countercurrent, NBUC, North Brazil Undercurrent, SEUC, South Equatorial Undercurrent, EUC, Equatorial Undercurrent, NEUC, North Equatorial Undercurrent. Station positions are indicated at the top of each panel. The red polygon identify the NBC and NBUC currents. Adapted from Goes et al. (2005). . . . . . . . . . . . . . . . . . . 
1.6 The current pathways for Tropical Water domain in study area. SEC: South Equatorial Current; NBUC: North Brazil Undercurrent; SEC: South Equatorial Current. Adapted from Krelling (2014), Schott et al. (1998) and Soutelino et al.

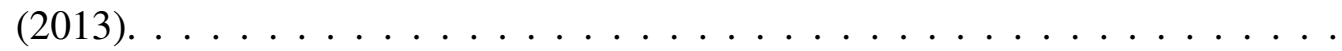

1.7 The current pathways for South Atlantic Central Water domain in study area. SEC: South Equatorial Current; NBUC: North Brazil Undercurrent; SEC: South Equatorial Current; SEUC: South Equatorial Undercurrent; P: Potiguar Eddy. Adapted from Cochrane et al. (1979), Schott et al. (1998), Silveira et al. (1994) and Soutelino et al. (2013). . . . . . . . . . . . . . . . . . . . .

1.8 The current pathways for Antarctic Intermediate Water domain in study area. SEC: South Equatorial Current; NBC: North Brazil Current; NBUC: North Brazil Undercurrent; SEUC: South Equatorial Undercurrent; P: Potiguar Eddy. Adapted from Schott et al. (1998) and Soutelino et al. (2013). . . . . . . . . . .

1.9 Seasonal cycles of NBC transport for the top $300 \mathrm{~m}$ (dashed line), for the 300-800-m depth range (short dashed line), and for the total upper ocean (0-800 $\mathrm{m})$. These seasonal cycles were created by computing monthly means of the respective NBC transport series from 1989 to 1991 current meter mooring data after smoothing with a 90-day low-pass filter. Standard errors for the monthly mean total $(0-800 \mathrm{~m})$ transport are indicated at right. Adapted from Johns et al.

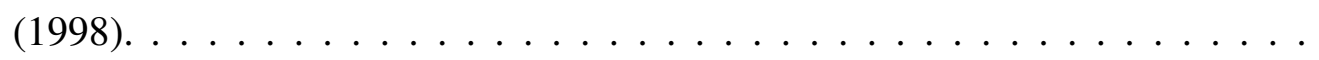

1.10 Seasonal cycle (superposition of fitted annual plus semiannual harmonics; Sv) of transport time series for NBUC. Also shown are arithmetic means (horizontal bars) calculated from the transport time series for all available 90 -day time periods centered at the times of the seasonal NBUC transport minima and maxima. Adapted from Schott et al. (2005). . . . . . . . . . . . . . . . . . . . . . .

1.11 The current pathways for South Atlantic Central Water domain in study area. EUC: Equatorial Undercurrent; SEC: South Equatorial Current; NBUC: North Brazil Undercurrent; SEUC: South Equatorial Undercurrent; P: Potiguar Eddy. Adapted from Cochrane et al. (1979), Krelling (2014), Schott et al. (1998), Silveira et al. (1994) and Soutelino et al. (2013). . . . . . . . . . . . . . . . . . . 
1.12 Left panel: The ADCP alongshore velocity section within Potiguar bight. The horizontal dashed black lines are the $\sigma_{\theta}=24.5$ and $\sigma_{\theta}=26.8$ isopycnal surface. Eastward velocities are positive. Right panel: The section geographic location. From Krelling (2014). . . . . . . . . . . . . . . . . . . .

1.13 The current pattern for South Atlantic Central Water domain in study area. ?: our study area. SEC: South Equatorial Current; NBUC: North Brazil Undercurrent; SEC: South Equatorial Current; SEUC: South Equatorial Undercurrent; P: Potiguar Eddy. Adapted from Schott et al. (1998) and Soutelino et al. (2013).

2.1 Type and distribution of insitu data set. The green line is the Brazil Navy's Oceano Norte I cruise route where were sampled both CTD and ADCP data in June 2001. The red dot is the PETROBRAS' current meter mooring position sampled from September 2007 to October 2007. . . . . . . . . . . . . . . .

2.2 Illustration for effects of the GYRO deviation. The blue arrow is the estimated velocity, the red arrow is the vessel velocity and the dashed arrows is its respectively errors. The ideal scenario shows a state that usually occurs when the vessel does not make sudden movements. Courtesy of Rafael Soutelino. . . . .

3.1 A: Hydrographic Brunt-Väisälä squared frequency profile. B: Vertical structure for equatorial pressure modes and its respective deformation radii in $\mathrm{km}$. Following the method described in Philander et al. (1989). . . . . . . . . . . . .

3.2 ON1 western alongshore velocity section. The vertical black scatter indicates the BAR1 current meter sensors vertical positions and the red dot is the mooring location. The horizontal dashed red lines are $\sigma_{\theta}=24.5$ and $\sigma_{\theta}=26.8$ isopycnal surfaces. The green line is the section location. Eastward velocities are positive.

3.3 The eastern alongshore velocity section. The horizontal dashed red lines is the $\sigma_{\theta}=24.5$ isopycnal. The green line is the section location. Eastward velocities

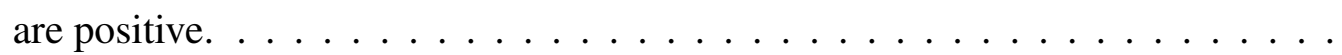

3.4 Upper panel: The 60-m velocity field (quiver plot) of the ADCP data from the Brazil Navy's Oceano Norte I cruise. Lower panel: Current pathways general pattern obtained by the velocity field. The red dot indicates the current meter mooring location. 
3.5 Upper panel: The 150-m velocity field (quiver plot) of the ADCP data from the Brazil Navy's Oceano Norte I cruise. Lower panel: Current pathways general pattern obtained by the velocity field. The red dot indicates the current meter

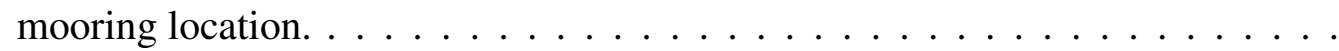

3.6 Upper panel: The 110-m velocity field (quiver plot) of the ADCP data from the Brazil Navy's Oceano Norte I cruise. Lower panel: Current pathways general pattern obtained by the velocity field. The red dot indicates the current meter

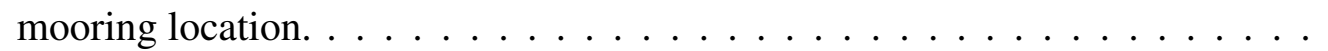

3.7 Left panel: The current meter mean alongshore velocity profile for the BAR1 current meter mooring. Right panel: Location (yellow star) and current pathways general pattern for $50 \mathrm{~m}$ (Red), $110 \mathrm{~m}$ (Light green) and $150 \mathrm{~m}$ (Dark green). Eastward velocities are positive. . . . . . . . . . .

3.8 The BAR1 current meter mooring data. The filled contours are the alongshore velocity time series at first $785 \mathrm{~m}(\mathbf{A})$ and the zoomed area $(\mathbf{B})$ marked with the dashed black line. . . . . . . . . . . . . . . . . . . . .

3.9 Monthly number of events per month graph for the 30-m current meter data of the BAR1 time series (year: 2007) . . . . . . . . . . . . . . . . . . .

3.10 Monthly number of events per month graph for the 150-m current meter data of

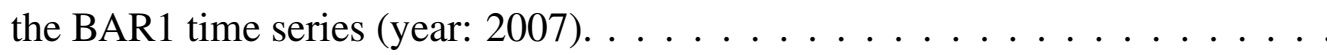

3.11 The EOF analysis for the alongshore velocity from PETROBRAS current meter mooring BAR1 at first $1850 \mathrm{~m}$ of depth. A: Entire time series. B: No-event period. C: During the events. The legend text is the explained variance for the

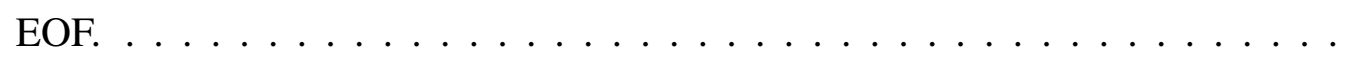

3.12 The EOFs $\left(A_{1}\right)$ and its respectively amplitudes $\left(A_{2}\right.$ and $\left.A_{3}\right)$ for entire time series of the alongshore velocity from BAR1 current meter mooring at first $350 \mathrm{~m}$ of depth. The legend text is the explained variance for the EOF. . . . . . . . . . .

3.13 The EOFs $\left(B_{1}\right)$ and its respectively amplitudes $\left(B_{2}\right.$ and $\left.B_{3}\right)$ for no-events period alongshore velocity from BAR1 current meter mooring at first $350 \mathrm{~m}$ of depth. The legend text is the explained variance for the EOF. . . . . . . . . .

3.14 The EOFs $\left(C_{1}\right)$ and its respectively amplitudes $\left(C_{2}\right.$ and $\left.C_{3}\right)$ the alongshore velocity, during the events, from BAR1 current meter mooring at first $350 \mathrm{~m}$ of depth. The legend text is the explained variance for the EOF. . . . . . . . . . . 
3.15 A: The BAR1 current meter mooring alongshore velocity time series at first 730 m. B: The $1^{\text {st }}$ EOF mooring data recomposition with the mean profile. . . . . .

3.16 A: The BAR1 current meter mooring alongshore velocity time series at first $730 \mathrm{~m}$. B: The $2^{\text {nd }}$ EOF mooring data recomposition with the mean profile. Eastward velocities are positive. . . . . . . . . . . .

3.17 A: TheBAR1 current meter mooring alongshore velocity time series at first 730 m. B: The $1^{\text {st }}$ and $2^{\text {nd }}$ EOF mooring data recomposition with the mean profile.

3.18 The BAR1 current meter mooring data EOF recomposition error for the $1^{\text {st }}(\mathbf{A})$, $2^{\text {nd }}(\mathbf{B})$ and both $1^{\text {st }}$ and $2^{\text {nd }}$ (C) EOFs.

4.1 The HYCOM alongshore velocity section corresponding to ONI's eastern VMADCP section. The horizontal dashed red lines are 24.5 and 26.8 isopycnals. The green line is the section location. $\ldots \ldots \ldots \ldots \ldots$

4.2 Left panel: The model mean alongshore velocity profile. Right panel: Location (yellow hexagon) and current pathways for $50 \mathrm{~m}$ (Red), $110 \mathrm{~m}$ (Light green) and $150 \mathrm{~m}$ (Dark green). . . . . . . . . . . . . . .

4.3 Comparison between the HYCOM synthetic mooring time series (B) and the BAR1 mooring data (A) for the eddy season (March-August). The filled contours represent the alongshore velocity. . . . . . . . . . . .

4.4 The EOF analysis model confirmation for the alongshore velocity. A: The model output with full vertical resolution. B: The model output linearly interpolated to the BAR1 current meter depths. C: The BAR1 current meter mooring. 44

4.5 The 9-year annual mean velocity (arrows) and vorticity (filled contours) fields obtained from the HYCOM output at $150 \mathrm{~m}$ (Lower panel) and $60 \mathrm{~m}$ (Upper panel). The red dashed straight line is the location for the synthetic velocity transect used to transport annual cycle analysis.

4.6 Current (transport per depth length) annual cycle analysis for a $39^{\circ} \mathrm{W}$ crossshore transect at $60 \mathrm{~m}$ (Upper panel) and $150 \mathrm{~m}$ (Lower panel). . . . . . . . . .

4.7 The 9-year mean velocity (arrows) and vorticity (filled contours) fields obtained from the HYCOM output at $60 \mathrm{~m}$. Upper panel: May. Lower panel: October.

4.8 The 9-year mean velocity (arrows) and vorticity (filled contours) fields obtained from the HYCOM output at 150 m. Upper panel: May. Lower panel: September. 
4.9 Every-two-day velocity (arrows) and vorticity (filled contours) fields for the HYCOM output at $150 \mathrm{~m}$ from 2007-03-31 to 2007-04-10. The red square signs the day which the synthetic velocity section is presented. . . . . . . . . .

4.10 The HYCOM alongshore velocity section at $40^{\circ} \mathrm{W}$ in $2007-04-04$. The horizontal dashed red lines are 24.5 and 26.8 isopycnals. The green line is the section location.

4.11 Every-two-day velocity (arrows) and vorticity (filled contours) fields for the HYCOM output at $150 \mathrm{~m}$ from 2007-02-17 to 2007-02-27. The red square signs the day which the synthetic velocity section is presented. . . . . . . . .

4.12 The HYCOM alongshore velocity section at $40^{\circ} \mathrm{W}$ in $2007-02-21$. The horizontal dashed red lines are 24.5 and 26.8 isopycnals. The green line is the section

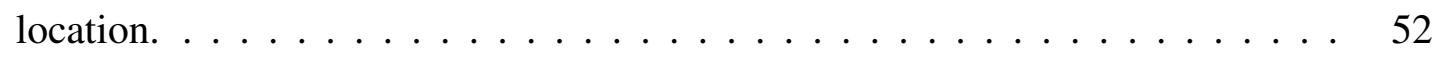

4.13 Every-two-day velocity (arrows) and vorticity (filled contours) fields for the HYCOM output at $60 \mathrm{~m}$ from 2001-07-09 to 2001-07-19. The red square signs the day which the VMADCP data was sampled. . . . . . . . . . 53

4.14 Every-two-day velocity (arrows) and vorticity (filled contours) fields for the HYCOM output at $150 \mathrm{~m}$ from 2001-07-09 to 2001-07-19. The red square signs the day which the VMADCP data was sampled. . . . . . . . . . . . 54 


\section{List of Tables}

1.1 The three water-mass composite which forms the NBC/NBUC system and its

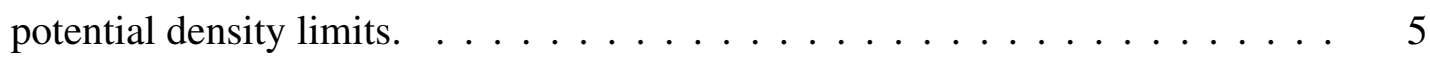

3.1 Deformation radii and Equivalent Depths . . . . . . . . . . . . . . . 21

3.2 The eastern ADCP section morphometric analysis of the Barreirinhas Eddy coastal lobe in terms of its alongshore (nearly zonal) velocities. Eastward velocities are positive . . . . . . . . . . . . . . . 23

3.3 Dimensionless numbers of its coastal alongshore velocity lobes. . . . . . . . . 27

3.4 The mean velocity profile for the mooring current meter data in entire time series and event occurrence period. . . . . . . . . . . . . . . . 30

4.1 Dimensionless number comparison computed for the HYCOM output and the ONI VMADCP data for the eastern transect. . . . . . . . . . . . . . 41

4.2 Morphometric comparison between the HYCOM alongshore velocity section and the ONI VMADCP data for the eastern transect. . . . . . . . . . . . . . . . . 42 


\section{List of Acronyms}

ADCP Acoustic Doppler Current Profiler

AAIW Antarctic Intermediate Water

BAR1 Barreirinhas 1 current meter mooring

BB Barreirinhas Bight

BC Brazil Current

BE Barreirinhas Eddy

CTD Condutivity, Temperature and Depth instrument

EOF Empirical Orthogonal Function

EIC Equatorial Intermediate Current

EUC Equatorial Undercurrent

HYCOM Hybrid Coordinate Model

IWBC Intermediate West Boundary Current

NADW North Atlantic Deep Water

NBC North Brazil Current

NBUC North Brazil Undercurrent

NICC North Intermediate Counter Current

ON1 Oceano Norte I cruise

TW Tropical Water

SACW South Atlantic Central Water

SEC South Equatorial Current

SEUC South Equatorial Undercurrent

SICC South Intermediate Counter Current

VMADCP Vessel Mounted Acoustic Doppler Current Profiler 


\section{Abstract}

The equatorial Brazilian margin is seen as a new frontier of mineral resources exploration, such as the Ceará and Barreirinhas oil-gas blocks. Nevertheless its economic relevance and contribution to heat and mass transport from south to north hemisphere, the North Brazil Current (NBC) and North Brazil Undercurrent (NBUC) has very few information in terms of its multiple retroflections and recirculations and the accompanying temporal variability. There is no report of the NBC/NBUC system between $0^{\circ}-3^{\circ} \mathrm{S}$. The Barreirinhas Bight, from $0^{\circ}-2^{\circ} \mathrm{S}$, has dimensions and similar bathymetric configuration to those of the Potiguar Bight. The Potiguar Eddy discovery invites to speculate whether similar vortical feature exists in the northern bight.

We employed quasi-synoptic VMADCP and CTD data from Brazilian Navy's cruise Oceano Norte 1 (June 2001) and a current meter mooring data ceded by PETROBRAS (2007). In order to expand the analyses spatially and temporally, we use the velocity, salinity and temperature fields from global HYCOM simulation reanalysis named Experiment 19.1 (from 2001 to 2009). We describe the morphometric and dimensionless parameters for each observed feature as it time variability with mean fields and event statistics. The EOF analysis was used to investigate the vertical patterns of variability and its relation to vortical features within the bight.

The NBC/NBUC jet recirculates and shed within Barreirinhas Bight two type of eddies, the near-surface (in TW domain) and the pycnoclinic (in SACW domain) eddy. The near-surface (pycnoclinic) eddy has $100 \mathrm{~m}(150 \mathrm{~m})$ of vertical extent and a cross-shore radius of about $35 \mathrm{~km}$ $(80 \mathrm{~km})$. The shallower one is anisotropic with a alongshore radius of $80 \mathrm{~km}$. They both occur mainly from March to August typically as 7-day recurrent events with higher number of events in May. The EOF calculation revealed us that the dominant patterns of variability are associated with current inversions compatible with the eddy structures which vary importantly in the vertical. These eddies are not stationary and they propagate westward and are destroyed while leaving the equatorial border of the bight. With a Rossby and Richardson number of $\mathrm{O}(1)$, a aspect ratio of $\mathrm{O}\left(10^{-3}\right)$ and a Burger number $\mathrm{O}(10)-\mathrm{O}\left(10^{2}\right)$, they are hydrostatic, submesoscale 
features with vortical dynamics governed by relative vorticity.

This is the first study of the NBC/NBUC jet within the Barreirinhas Bight and, thus, it is the first description for the Barreirinhas Eddies.

Keywords: North Brazil Current, North Brazil Undercurrent, Eddy, Shedding, Submesoscale. 


\section{Resumo}

A margem equatorial brasileira tem sido vista como uma nova fronteira na exploração de recursos minerais marinhos, a exemplo da consessão dos blocos exploratórios do Ceará e Barreirinhas. Apesar da grande importância econômica e contribuição no transporte de massa e calor entre hemisférios, a Corrente Norte do Brasil (CNB) e a Subcorrente Norte do Brasil (SNB) são pouco estudadas em termos de suas múltiplas retroflexões e recirculações e sua variabilidade temporal. Não há nenhum estudo sobre o sistema CNB/SNB entre $0^{\circ}-3^{\circ} \mathrm{S}$. A Bacia de Barreirinhas, entre $0^{\circ}-2^{\circ} \mathrm{S}$, possui dimensões e configuração batimétrica muito similar à Bacia Potiguar e a recente descoberta do Vórtice Potiguar nos leva a especular se uma estrutura similar existe em seu domínio.

Usamos dados quasi-sinóticos de ADCP e CTD do cruzeiro da Marinha do Brasil Oceano Norte 1 (Junho de 2001) e um fundeio correntográfico cedido pela PETROBRAS (2007). Para expandir espacialmente e temporalmente a análise, usamos os campos de velocidade, salinidade e temperatura da simulação global do HYCOM, a reanálise do experimento 19.1 (de 2001 a 2009). Nós descrevemos os parâmetros não-dimensionais e morfométricos para cada feição observada e a sua variabilidade temporal foi analisada através de campos médios e estatística de eventos. A análise de EOFs foi utilizada para investigar os padrões verticais de variabilidade e sua relação com estruturas vorticais dentro da bacia.

O jato da $\mathrm{CNB} / \mathrm{SNB}$ recircula a propaga vórtices dentro da Bacia de Barreirinhas em dois tipos de fenômenos, o de superfície (no domínio da Água Tropical) e o de nivel picnoclínico (no domínio da Água Central do Atlântico Sul). O vórtice de superfície (picnoclínico) tem 100 m $(150 \mathrm{~m})$ de extensão vertical e um raio normal à costa de $35 \mathrm{~km}(80 \mathrm{~km})$. O mais raso é anisotrópico, com um raio paralelo à costa de $80 \mathrm{~km}$. Ambos ocorrem principalmente entre março e agosto como eventos recorrentes de 7 dias de duração. O maior número de eventos ocorre em maio. O cálculo das EOFs revelaram que os padrões dominantes de variabilidade estão associados com as inversões de corrente compatíveis com a estrutura vertical dos vór- 
tices. Como dito anteriormente, estes vórtices não são estacionários e estes se propagam para oeste, sendo destruídos quando interagem com a borda equatorial da bacia. Com um número de Rossby e Richardson de $\mathrm{O}(1)$, uma razão de aspecto de $\mathrm{O}\left(10^{-3}\right)$ e um número de Burger entre $\mathrm{O}(10)$ e $\mathrm{O}\left(10^{2}\right)$, estes vórtices são estruturas hidrostáticas, de submesoescala, com dinâmica governada pela vorticidade relativa.

Este é o primeiro estudo do jato da CNB/SNB no domínio da Bacia de Barreirinhas e, assim, esta é a primeira descrição dos Vórtices de Barreirinhas.

Descritores: Corrente Norte do Brasil, Subcorrente Norte do Brasil, Vórtice, Propagação, Submesoescala. 


\section{Chapter 1}

\section{Introduction}

This dissertation investigates the recurrent formation of anticyclonic features associated with the North Brazil Current (NBC) and North Brazil Undercurrent (NBUC) within the Barreirinhas Sedimentary Basin off the Piauí State $\left(40^{\circ} \mathrm{W}-44^{\circ} \mathrm{W}\right)$. In the following sections, we review the literature about the NBC/NBUC system off the Northeast Brazilian coast, describe the thesis motivation, formulate the scientific hypotheses to be tested and present the objectives through which we reach our goal.

\subsection{The North Brazil Current Recent History}

The two main western currents off the Brazilian coast are the Brazil Current (BC), which flows southward, and the North Brazil Current (NBC), flowing northward. Both currents are formed by multiple branches of the South Equatorial Current (SEC) which reaches the continental slope and generates bifurcations at different latitudes and depths. The formation of the NBUC is far from being simple to describe. The NBC, as we shall see in the next paragraphs, starts as a subsurface-intensified jet referred in the literature as the NBUC (Figure 1.1).

This latter current originates further south and its vertical extent reaches the surface at about $14^{\circ}-15^{\circ} \mathrm{S}$ where the SEC southern branch impinges itself onto the continental slope. The NBC/NBUC system is the one which flows next to the continental shelf break in the northeast Brazil (Figure 1.2) and so, it will be the focus of this large scale circulation description to be presented next.

\footnotetext{
${ }^{2} \mathrm{We}$ here express the potential density values as potential density conventional anomalies $\sigma_{\theta}=\rho_{\theta}-1000$. Where the $\rho_{\theta}$ is the full potential density. The notation $\sigma_{0}$ and $\sigma_{1}$ corresponds to the conventional potential density relative
} 

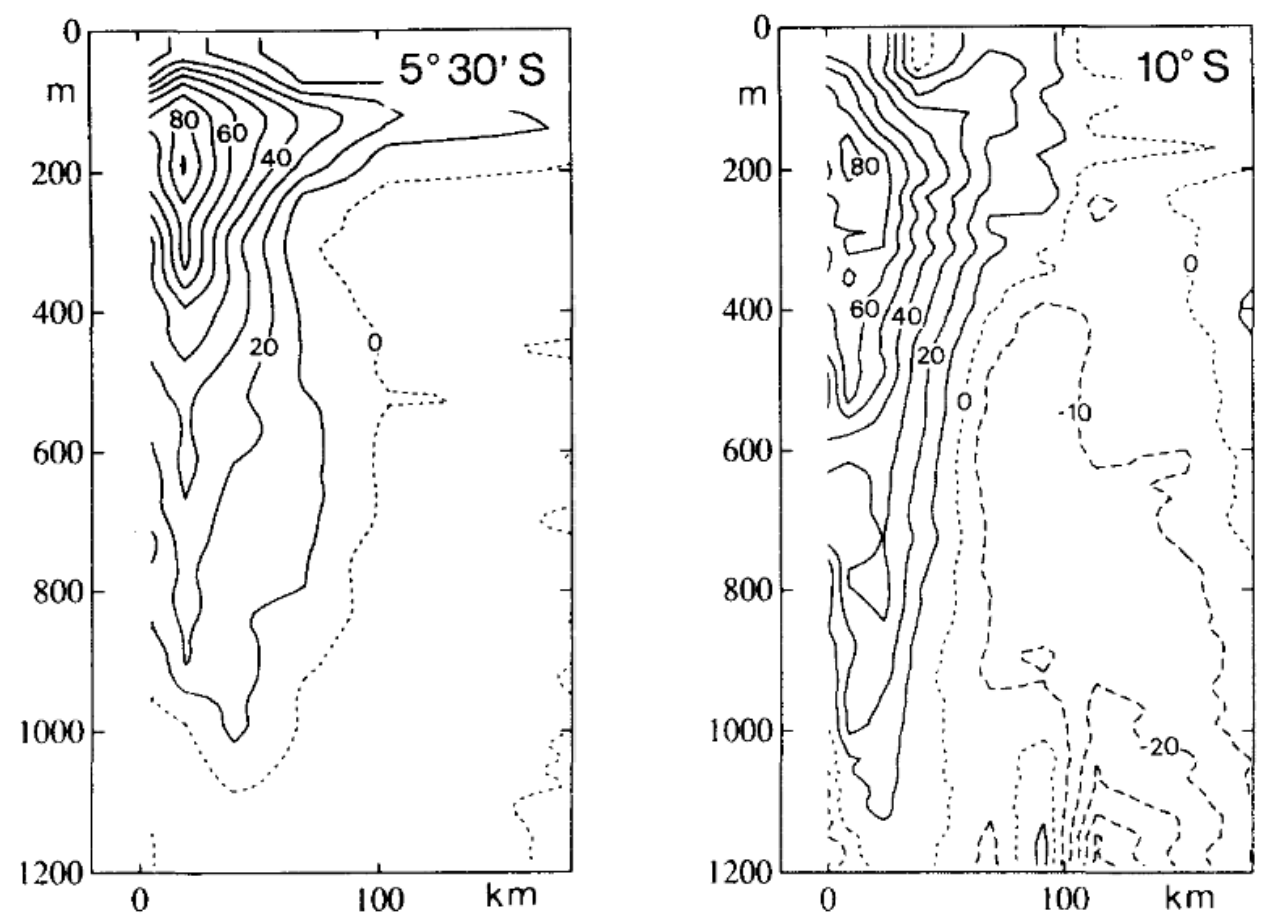

Figure 1.1: The North Brazil Undercurrent velocity distribution versus offshelf distance at $5.5^{\circ} \mathrm{S}$ and $10^{\circ} \mathrm{S}$ in November 1992 from the lowered-ADCP rotated to show the along-shore component. From Stramma et al. (1995).
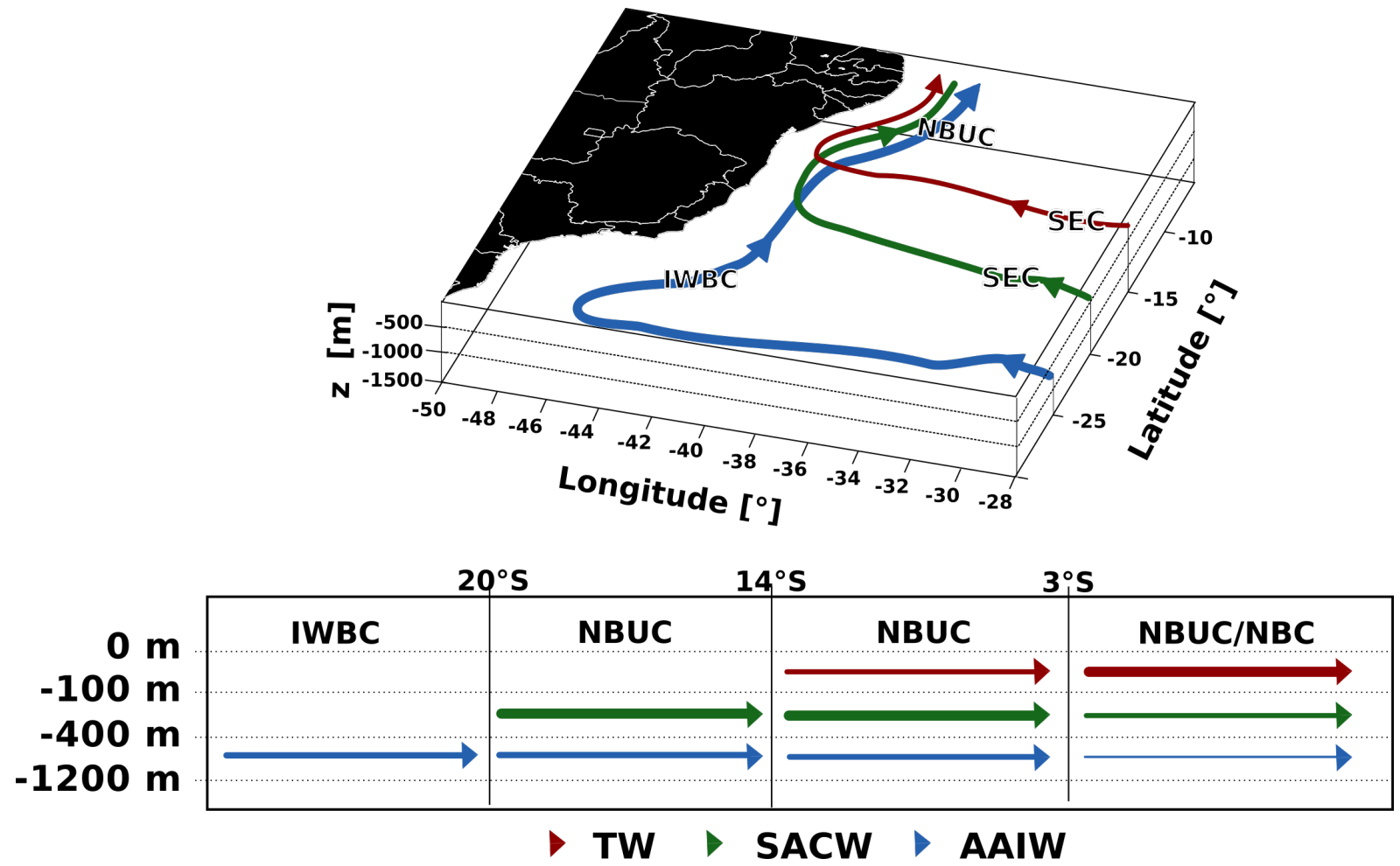

Figure 1.2: Upper panel: 3D scheme representing the NBUC formation in 3 different layers. Only the northward flow for each SEC bifurcation is presented. Lower panel: Scheme representing the NBUC's formation and transformation in different latitudes. TW: Tropical Water from the surface to the $\sigma_{0}^{2}=24.5$ isopycnal surface, SACW: South Atlantic Central Water from $\sigma_{0}=24.5$ to the $\sigma_{0}=26.8$ isopycnal surfaces, AIW: Antartic Intermediate Water from $\sigma_{0}=26.8$ to the $\sigma_{1}=32.15$ isopycnal surfaces. Adapted by Soutelino et al. (2013). 
The NBUC and NBC are parts of the same system. The NBUC, in particular, originates around $20^{\circ} \mathrm{S}$, where the pycnoclinic SEC bifurcation transporting the South Atlantic Central Water (SACW) sums up to the Antarctic Intermediate Water (AAIW) flow characterizing a subsurface current with its core around 150 meters depth. The AAIW underflow was first described Boebel et al. (1999) and its vertical structure unraveled by Da Silveira et al. (2004) (Figure 1.3).

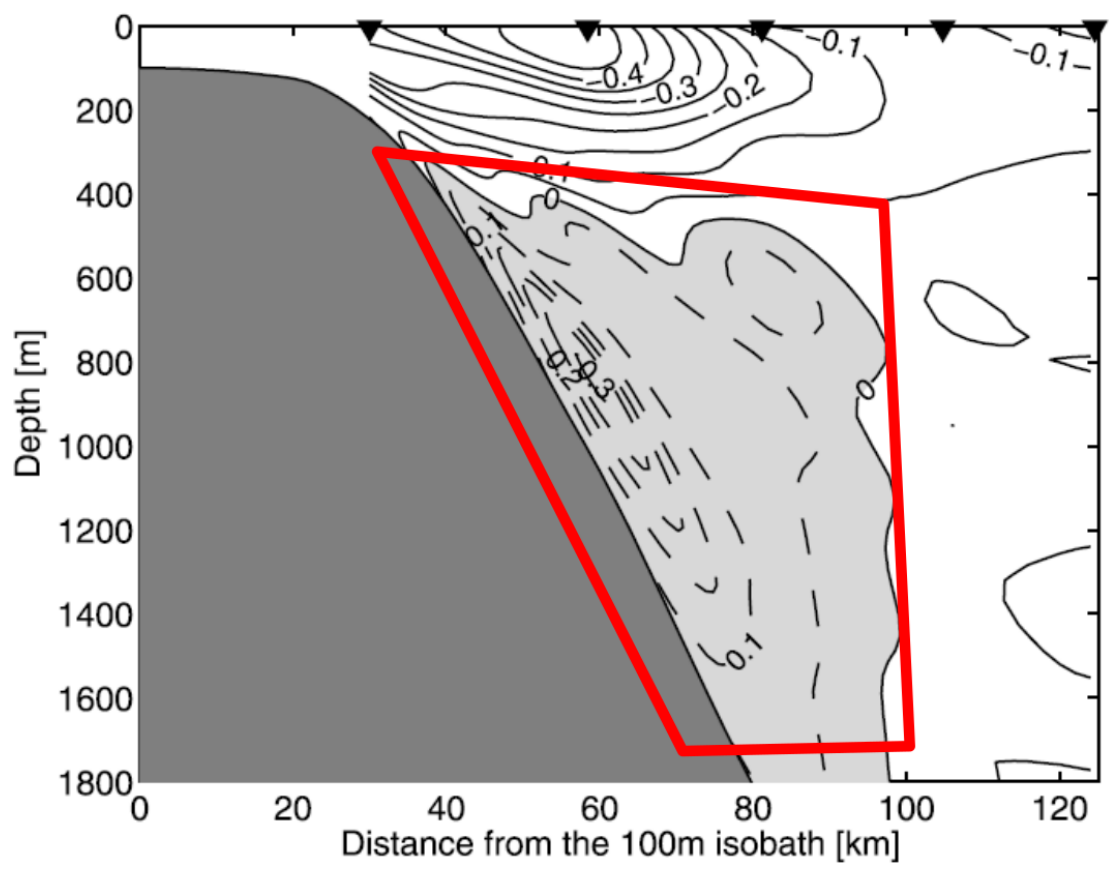

Figure 1.3: The April 1983 alongshore velocity section off Cape Frio $\left(23^{\circ} \mathrm{S}\right)$. Positive velocities are northeastward. Contour intervals are $0.05 \mathrm{~m} \mathrm{~s}^{-1}$. The red contour identify the IWBC lobe. Adapted from Da Silveira et al. (2004).

Until the 80's, it was believed that both Brazil Current (BC) and North Brazil Current (NBC) were formed in the South Equatorial Current (SEC) central branch bifurcation next to cape São Roque in $5^{\circ} 30^{\prime} \mathrm{S}$. This subsurface flow was first described by Silveira et al. (1994) estimating the geostrophic stream function and velocity sections with hydrographic Nansen bottles data. The authors also used meteorological data and concluded that the historically described southward surface flow in this area is explained by the Ekman drift (Figure 1.4).

Therefore, there is no bifurcation next to São Roque cape, but the SEC's central branch simply adds an upper level flow to the NBUC transport. This first description of the NBUC characterized it as a subsurface current centered at about 100-200 m transporting $21 \mathrm{~Sv}$ (1 Sv = $10^{6} \mathrm{~m}^{3} \mathrm{~s}^{-1}$ ). The supposed origin of the NBC results of a $36 \mathrm{~Sv}$ flow where the NBUC gains the contribution to its surface flow from the central branch of the SEC north of $4.5^{\circ} \mathrm{S}$.

Besides the first description by Silveira et al. (1994), the first characterization of the NBUC flow as an entire different current was done by Stramma et al. (1995). Using hydrographic and 

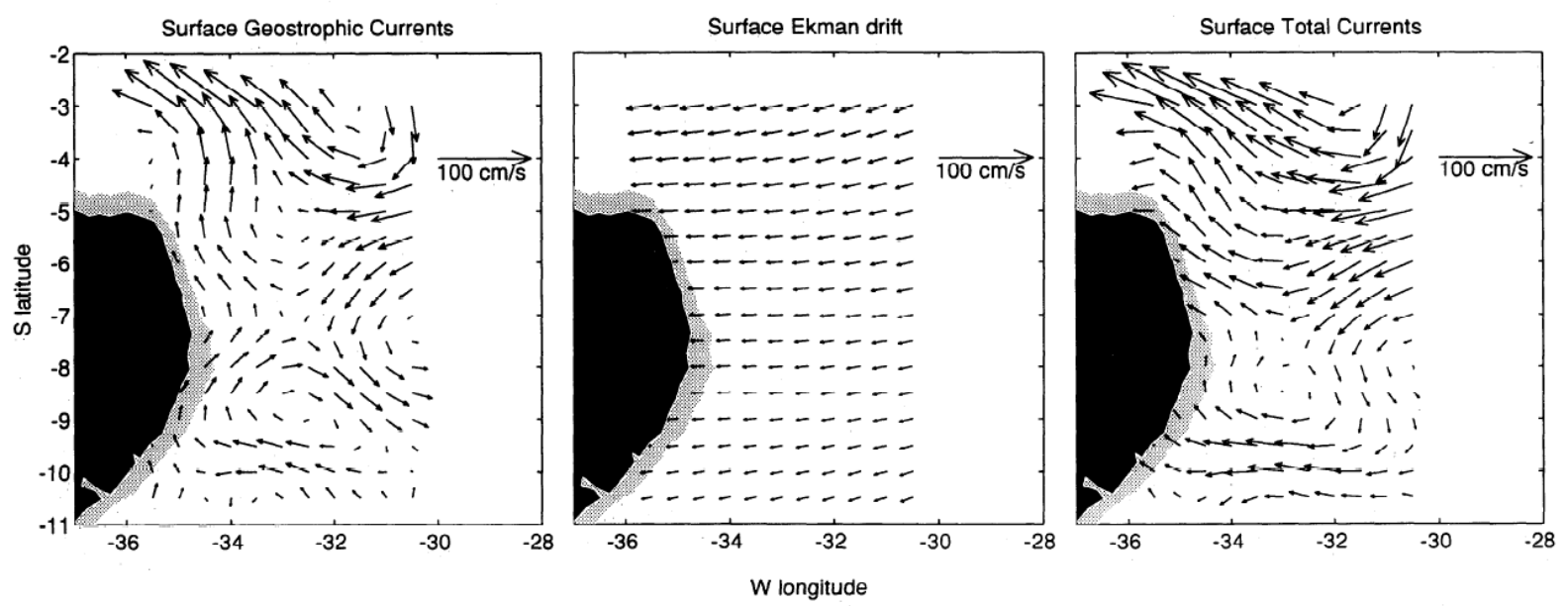

Figure 1.4: The surface current field including (left) geostrophic component, (middle) Ekman drift component and (right) total (i.e., sum of fields in left and middle panels). Velocity vectors are in centimeters per second. From Silveira et al. (1994).

lowered and vessel-mounted Acoustic Doppler Current Profiler (ADCP) the authors described it as a subsurface current with its core exceeding $0.9 \mathrm{~m} \mathrm{~s}^{-1}$ at about 200 meters depth and transporting more than $22 \mathrm{~Sv}$ (first $1000 \mathrm{~m}$ ). They calculated the Ekman transport too, confirming the Silveira et al. (1994) results and concluding that it could be the reason that it is a undercurrent. Comparing the hydrographic data with the lowered-ADCP, they got that the best no motion level to the geostrophic computations is the density surface of $32.15 \mathrm{~kg} \mathrm{~m}^{-3}$, which approximately coincides with the interface between the Antarctic Intermediate Water (AAIW) and the North Atlantic Deep Water (NADW).

The first study discussing the NBC/NBUC system at different levels was carried out by Schott et al. (1995). The authors, employing Conductivity, Temperature and Pressure (CTD) and ADCP data, inferred the origin of the NBC/NBUC transport at different layers. At surface, more than $80 \%$ of the NBC transport (first 100 meters) comes from the South Equatorial Current central branch, that is, from low latitudes. In contrast, the origin of the transport in the SACW and AAIW domain is from the NBUC jet south $10^{\circ} \mathrm{S}$. They also described the possible influence of the boundary current system with the equatorial currents formation, due its multiple retroflections north of $7^{\circ} \mathrm{S}$.

Thus, the NBUC, which is originated by the sum of Intermediate Western Boundary Current (IWBC) and the northward flow of $20^{\circ} \mathrm{S}$ SEC's SACW bifurcation, is organized from intermediary level to surface reaching its fullness north of $15^{\circ} \mathrm{S}$. From this latitude, toward equator, this current receives contribution from shallower SEC branches and suffers a series of pycnocline retroflections. Therefore, the NBUC, through its domain, decharacterizes from a pycnocline's 


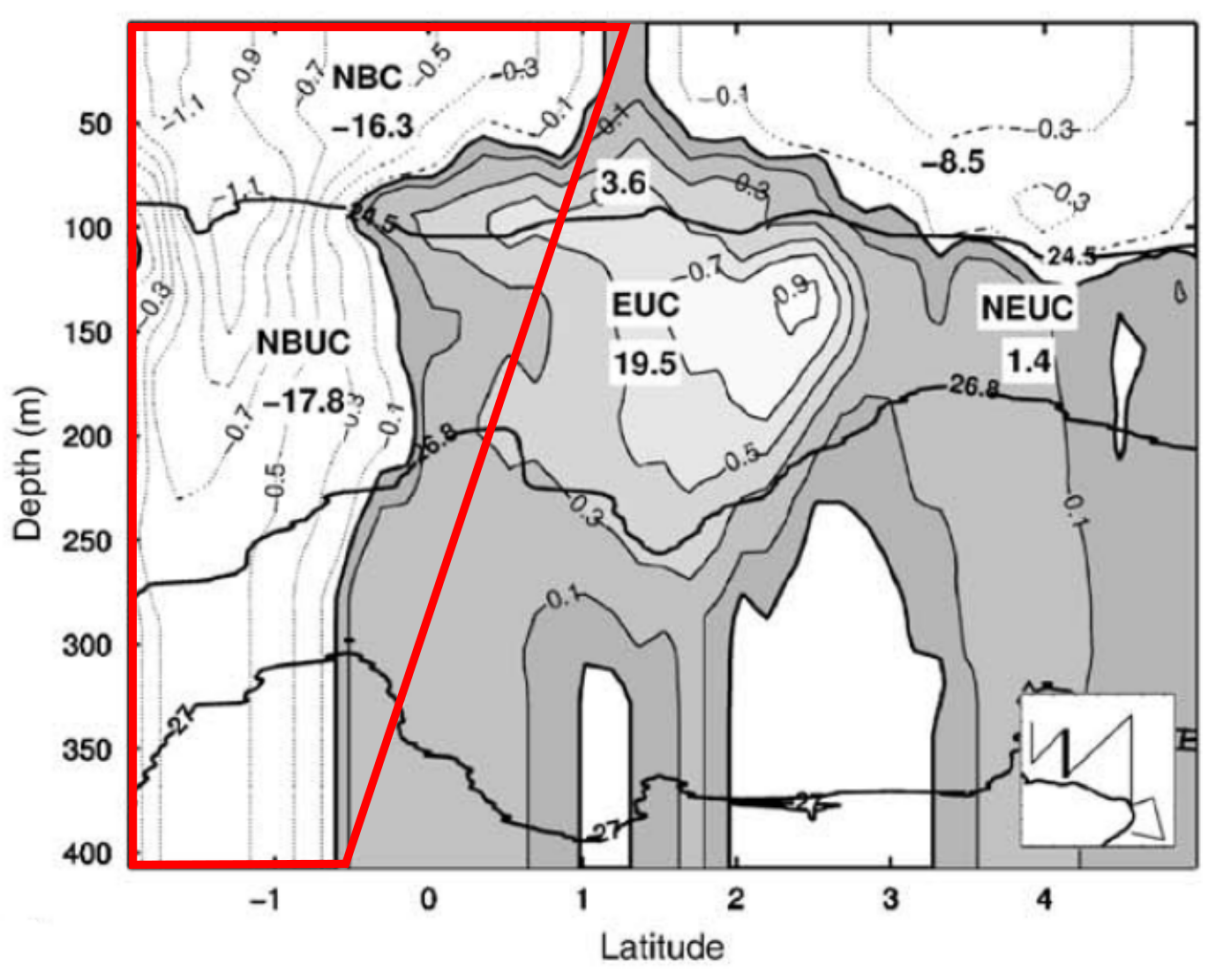

Figure 1.5: Vertical sections of the eastward component of speed $\left(\mathrm{m} \mathrm{s}^{-1}\right)$ for $41^{\circ} \mathrm{W}$ transect. The 24.5 and 26.8 isopycnal surfaces and transport of the major currents are also given. NBC, North Brazil Current, SEC, South Equatorial Current, NECC, North Equatorial Countercurrent, NBUC, North Brazil Undercurrent, SEUC, South Equatorial Undercurrent, EUC, Equatorial Undercurrent, NEUC, North Equatorial Undercurrent. Station positions are indicated at the top of each panel. The red polygon identify the NBC and NBUC currents. Adapted from Goes et al. (2005).

level current to a parabolic shaped surface jet, called North Brazil Current (NBC,Figure 1.5), that crosses the equator.

To illustrate this current system, its multiple retroflections and interactions with the equatorial currents within our study area we will present a current pathways maps adapted from Schott et al. (1998), Krelling (2014) and Soutelino et al. (2013) to a three water-mass composite at first $1200 \mathrm{~m}$, according to Table 1.1.

Table 1.1: The three water-mass composite which forms the NBC/NBUC system and its potential density limits.

\begin{tabular}{lc}
\hline Water mass & Potential density limits \\
\hline Tropical Water (TW) & $\sigma_{0}>24.5$ \\
South Atlantic Central Water (SACW) & $24.5<\sigma_{0}<26.8$ \\
Antarctic Intermediate Water (AAIW) & $\sigma_{0}>26.8 \wedge \sigma_{1}<32.15$ \\
\hline
\end{tabular}




\subsection{Layered current patterns}

\subsubsection{Tropical Water}

The shallowest water mass in the region is the Tropical Water $(0-100 \mathrm{~m}$ depth on average). On its domain, the currents pathways are presented in Figure 1.6. The SEC central branch reaches the Brazil continental margin intensifying the NBUC transport near the surface and forming its surface core, the NBC. Due the NBC retroflection, far to the north of $2^{\circ} \mathrm{N}$, there is a offshore eastward flow: the Equatorial Undercurrent (EUC) signature averaged over the upper $100 \mathrm{~m}$.

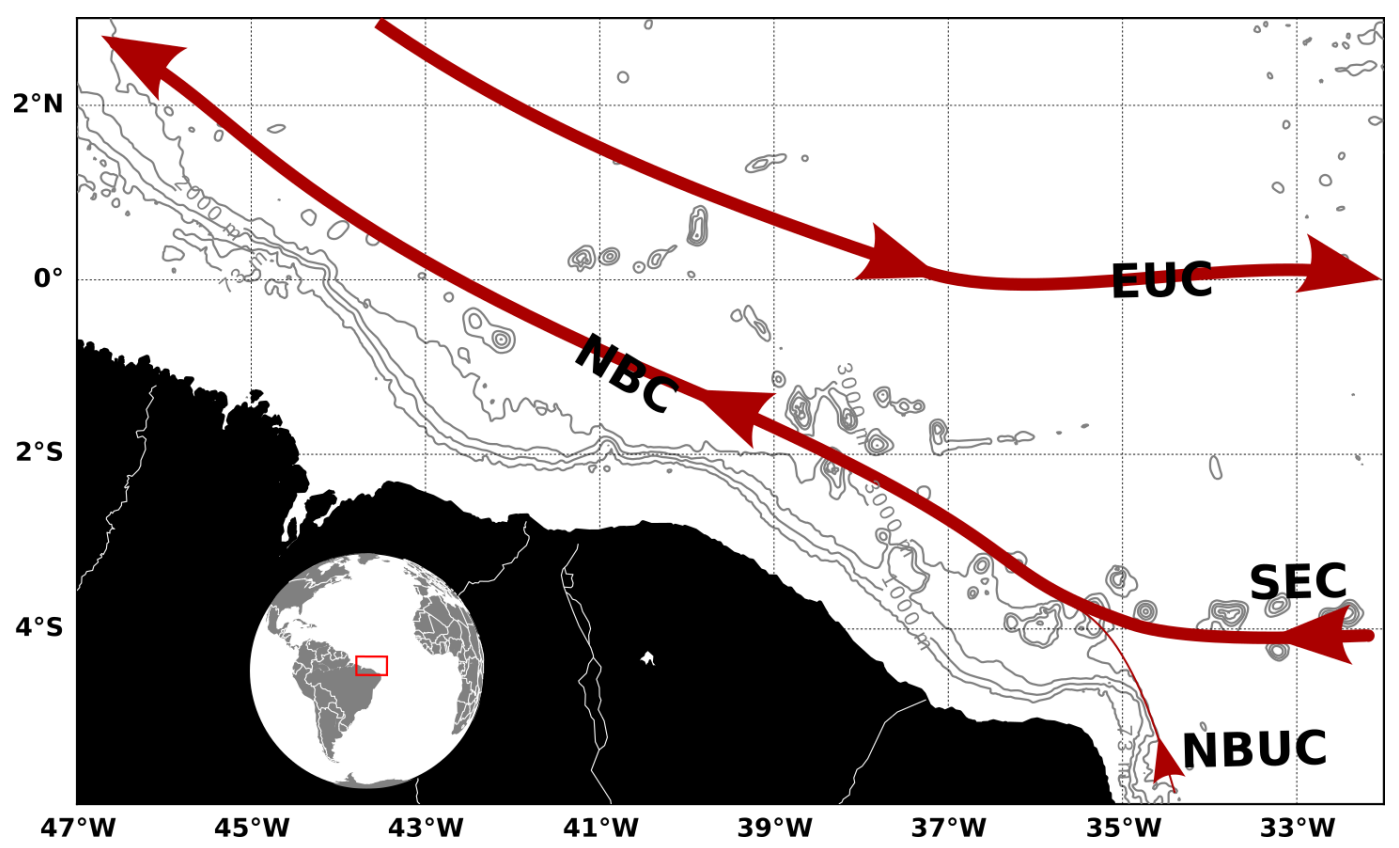

Figure 1.6: The current pathways for Tropical Water domain in study area. SEC: South Equatorial Current; NBUC: North Brazil Undercurrent; SEC: South Equatorial Current. Adapted from Krelling (2014), Schott et al. (1998) and Soutelino et al. (2013).

\subsubsection{South Atlantic Central Water}

On the SACW domain (100-400 m depth on average) we can see in the Figure 1.7 that, at this depth, the boundary current undergoes a series of retroflections with its interaction with the equatorial currents system. These retroflections contributes to a change in the boundary current pattern from a 150-m subsurface current (NBUC) in its origin to a surface maximum parabolic shaped current (NBC). 


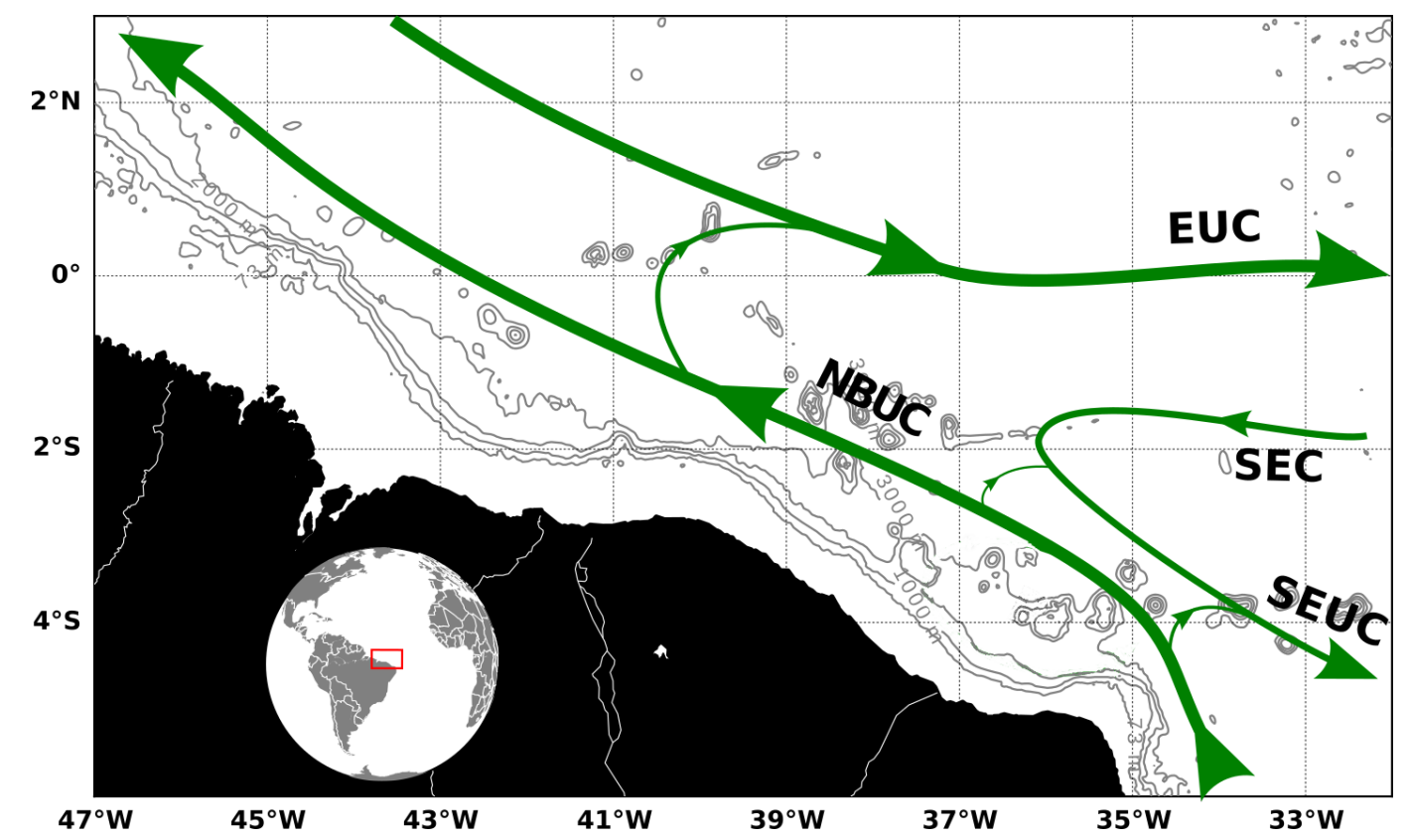

Figure 1.7: The current pathways for South Atlantic Central Water domain in study area. SEC: South Equatorial Current; NBUC: North Brazil Undercurrent; SEC: South Equatorial Current; SEUC: South Equatorial Undercurrent; P: Potiguar Eddy. Adapted from Cochrane et al. (1979), Schott et al. (1998), Silveira et al. (1994) and Soutelino et al. (2013).

\subsubsection{Antarctic Intermediate Water}

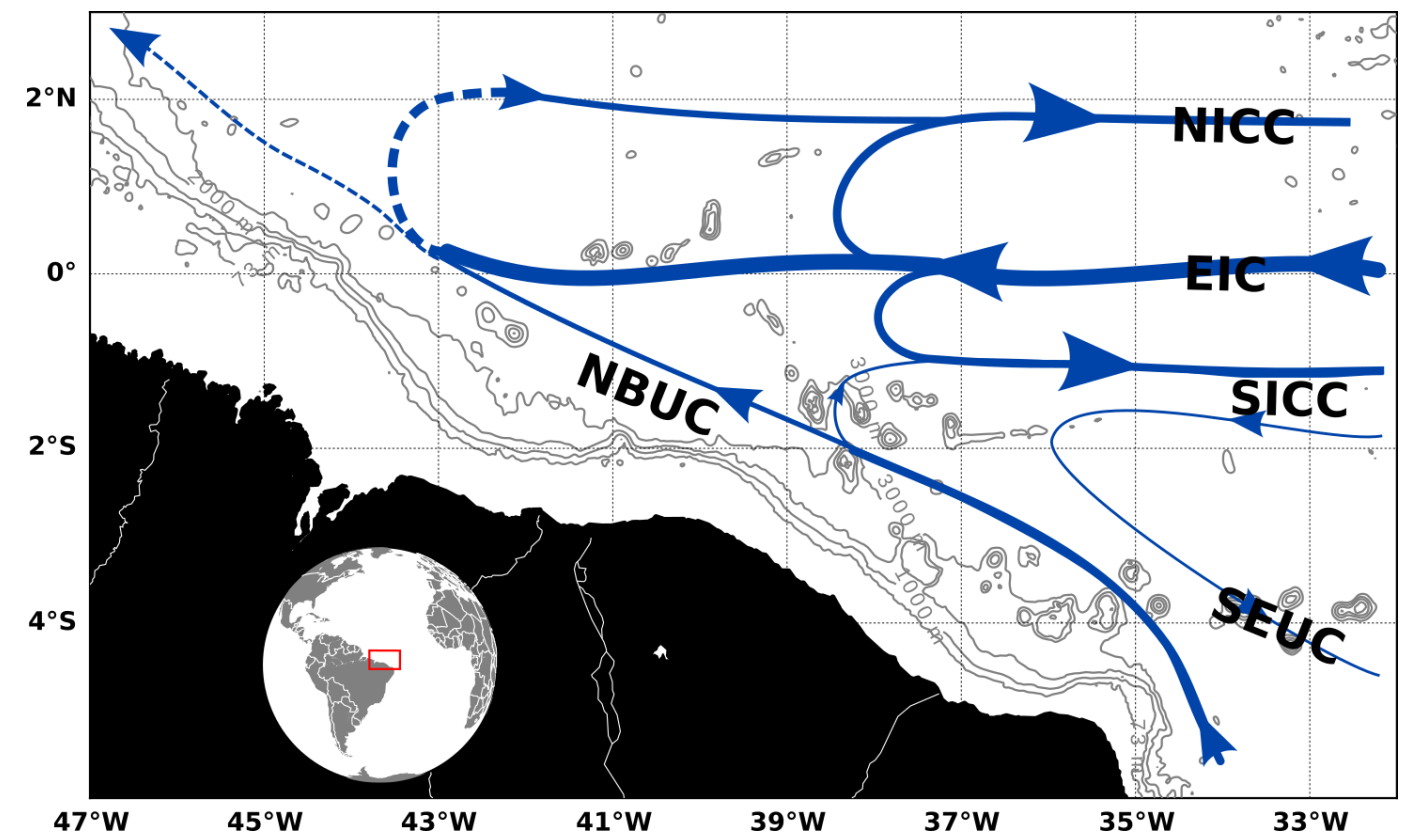

Figure 1.8: The current pathways for Antarctic Intermediate Water domain in study area. SEC: South Equatorial Current; NBC: North Brazil Current; NBUC: North Brazil Undercurrent; SEUC: South Equatorial Undercurrent; P: Potiguar Eddy. Adapted from Schott et al. (1998) and Soutelino et al. (2013).

In the AAIW domain (400-1200 m depth on average, Figure 1.8), the weak signature of the boundary current undergoes retroflections interacting with the intermediate equatorial cur- 
rents (the SICC, the EIC and the NICC) forming the intermediate counter currents. the SEC bifurcation on these depths is far south (around $28^{\circ} \mathrm{S}$ ).

\subsection{Seasonal and Intraseasonal Variability}

The temporal variability of the NBC/NBUC current system has been studied primarily by current meter mooring and lowered ADCP data. Johns et al. (1998) investigated its annual cycle at $7^{\circ} \mathrm{N}$ and computed monthly means of the volume transport after smoothing the series with a 90-day low-pass filter using current meter mooring lines (Figure 1.9). The maximum near-surface (0-300m) transport occurs in July-August and its minimum, in April-May. However, virtually no annual cycle signal was detected in the intermediate level (300-800m, mostly AAIW flow).

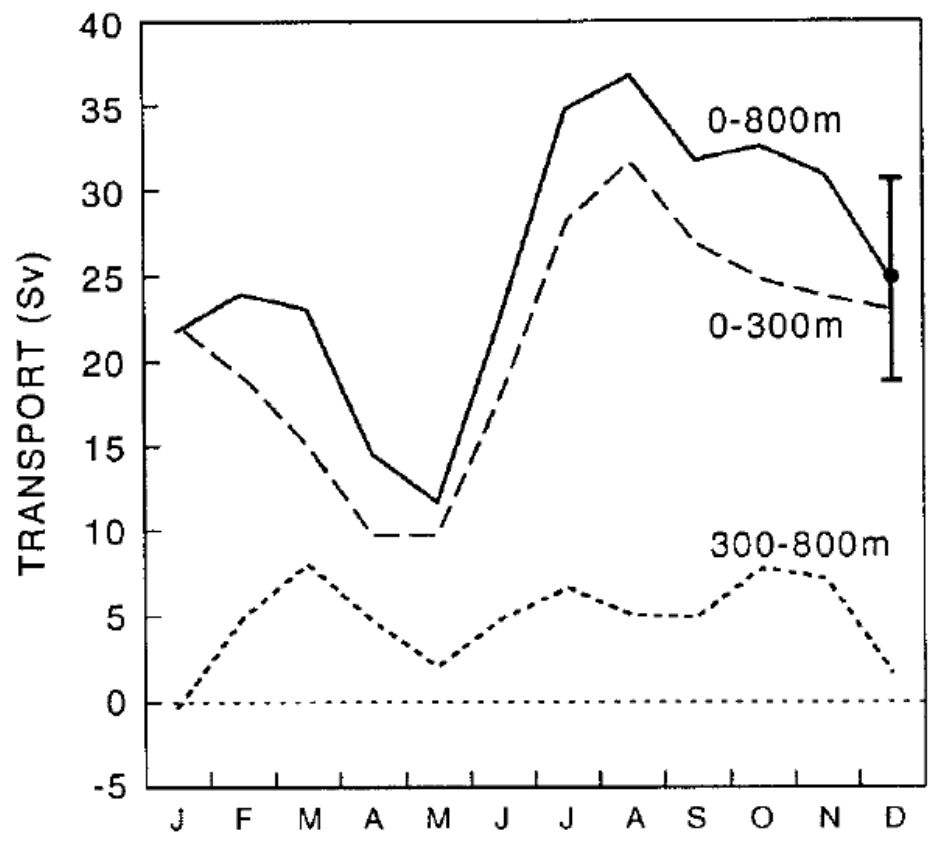

Figure 1.9: Seasonal cycles of NBC transport for the top $300 \mathrm{~m}$ (dashed line), for the 300-800-m depth range (short dashed line), and for the total upper ocean $(0-800 \mathrm{~m})$. These seasonal cycles were created by computing monthly means of the respective NBC transport series from 1989 to 1991 current meter mooring data after smoothing with a 90-day low-pass filter. Standard errors for the monthly mean total $(0-800 \mathrm{~m})$ transport are indicated at right. Adapted from Johns et al. (1998).

Further to the south, near to the NBUC origin site, Schott et al. (2005) studied the annual cycle of the transport finding the same transport maximum in July, but a minimum transport in November (Figure 1.10). These authors found a semiannual component as strong as the annual cycle in their time series. We can also crudely estimate semiannual component for the Johns et al. (1998) as being the difference between the maximum to the minimum, which yields to 
100 days. By merely inspecting and comparing Figure 1.9 and Figure 1.10, we observed that seasonal cycle changes somewhat towards north, as also the main western boundary current changes its structure due the impinging branches of the SEC.

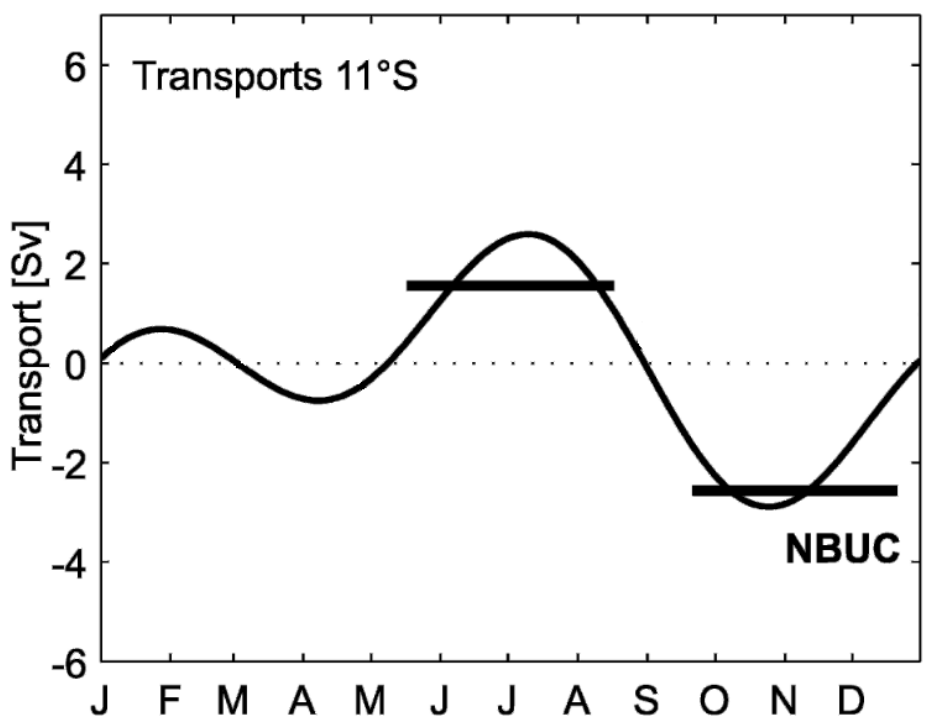

Figure 1.10: Seasonal cycle (superposition of fitted annual plus semiannual harmonics; Sv) of transport time series for NBUC. Also shown are arithmetic means (horizontal bars) calculated from the transport time series for all available 90-day time periods centered at the times of the seasonal NBUC transport minima and maxima. Adapted from Schott et al. (2005).

Most part of the previous works about the NBC/NBUC aimed to understand its surface retroflection and eddy shedding between $4^{\circ} \mathrm{N}-8^{\circ} \mathrm{N}$. Described mainly by hydrographic data in the first works (Cochrane et al., 1979; Bruce et al., 1985), it was believed that these features were stationary. The first work which explained the variability of the eddy-shedding regime was conducted by Johns et al. (1990). The authors used both mooring current meter and sea-color satellite imagery data. They identified a $\sim 50$-day periodicity in the upper level and, using color imagery data, they suggested that it is related to a northwestward propagating eddies that is a result of the NBC retroflection break off. The authors associated this variability to dispersive Rossby waves coming from the ocean interior and propagating northwestward bordering the shelf break. We connect this information with the finding by Richardson and Reverdin (1987), which using ship drift data detected the same band variability on the SEC between $2^{\circ} \mathrm{S}-8^{\circ} \mathrm{S}$.

Following Johns et al. (1990), Schott et al. (1993) analyzed the NBC intraseasonal variability on a mooring line deployed at the equator and at $40^{\circ} \mathrm{W}$. The latter authors found two main bands of variability: a 40-60 days and 25-35 days. While the 40-60day wave was linked to the same phenomenon described by the former authors: dispersive planetary waves. The shorter period oscillation was only later explained by another time series of current meter mooring lines at 
$4^{\circ} \mathrm{N}$ by Johns et al. (1998): they are equatorially-trapped Yanai waves. These waves reach the western boundary and monthly modulate the NBC.

The only study dealing with intraseasonal variation near the NBUC origin site at $10^{\circ} \mathrm{S}$ is Veleda et al. (2012). These authors indentified a 14-20day band on the NBUC inshore border adjacent to the shelf break. The exponentially-decaying velocity profile led the authors to suggest that the oscillations are due to coastally-trapped waves.

\subsection{The Potiguar Bight}

North of Cape São Roque, the Northeast Brazilian continental margin changes its orientation forming a system of two bights towards the equator. The southern bight is centered at $4^{\circ} \mathrm{S}$ and called the Potiguar Bight; the northern one is centered at $2^{\circ} \mathrm{S}$, called the Barreirinhas Bight (Mohriak, 2003). Marin (2009) and Krelling (2014) described a pycnocline eddy at Potiguar Bight.

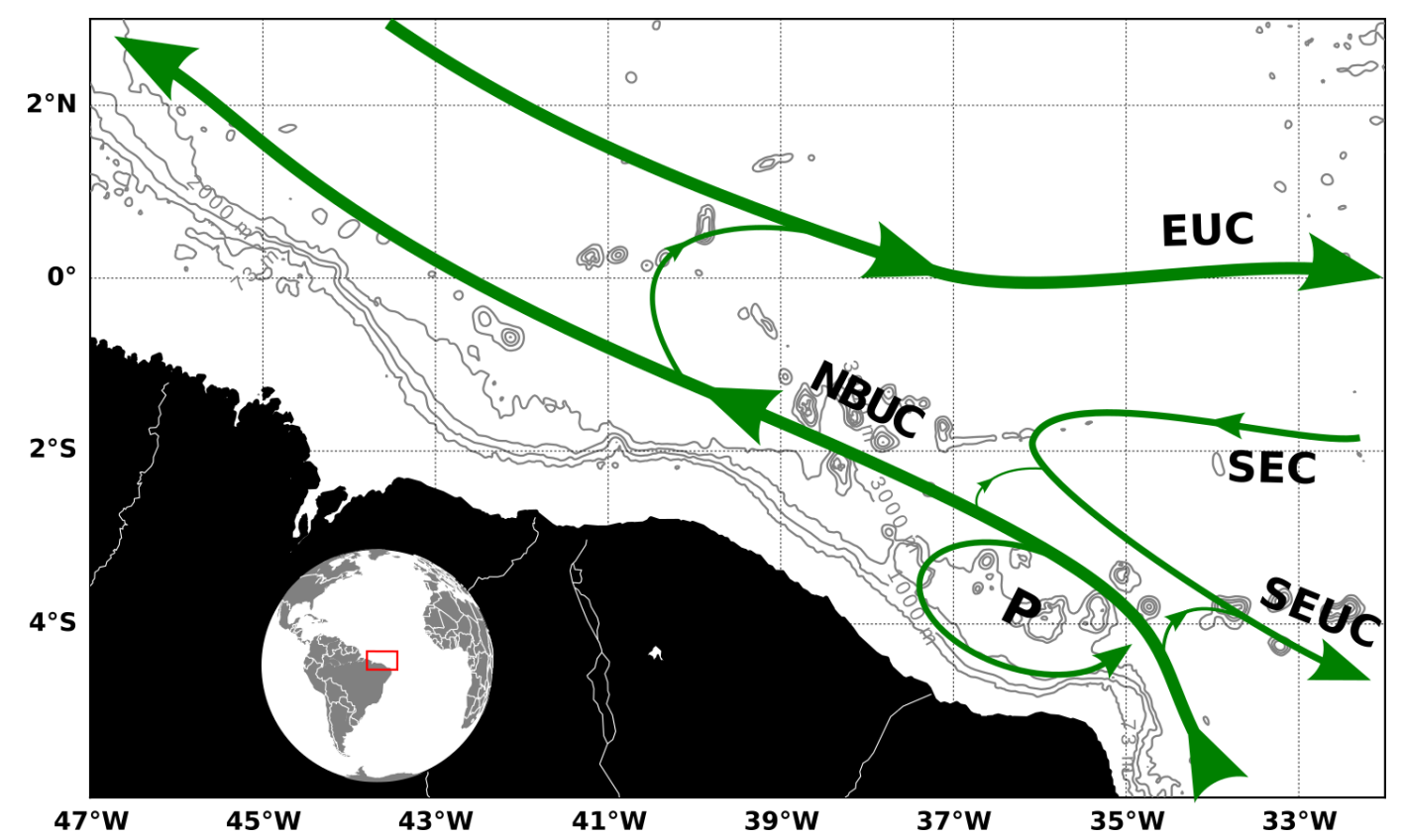

Figure 1.11: The current pathways for South Atlantic Central Water domain in study area. EUC: Equatorial Undercurrent; SEC: South Equatorial Current; NBUC: North Brazil Undercurrent; SEUC: South Equatorial Undercurrent; P: Potiguar Eddy. Adapted from Cochrane et al. (1979), Krelling (2014), Schott et al. (1998), Silveira et al. (1994) and Soutelino et al. (2013).

Krelling (2014) used a combination of hydrographic quasi-synoptic cruises, current meter moorings and satellite altimetry data to conclude that this eddy is a permanent feature modulated with intraseasonal variations. It is a stationary NBUC anticyclonic meander. Krelling (2014) found a clear and single dominant period band centered in 28 days. These oscillations seem to 
be linked to zeroth meridional mode structure (.ie., gaussian shaped amplitude envelope) in the southern hemisphere of the Yanai waves detected by Schott et al. (1993) and Johns et al. (1998) in similar latitudes of northern hemisphere.

This feature is within the SACW domain and its vertical extent is from 100 to $250 \mathrm{~m}$ depth, where its maximum of $0.6 \mathrm{~m} \mathrm{~s}^{-1}$ it located at about $175 \mathrm{~m}$. The horizontal extent of its coastal lobe is around $90 \mathrm{~km}$ (Figure 1.12).
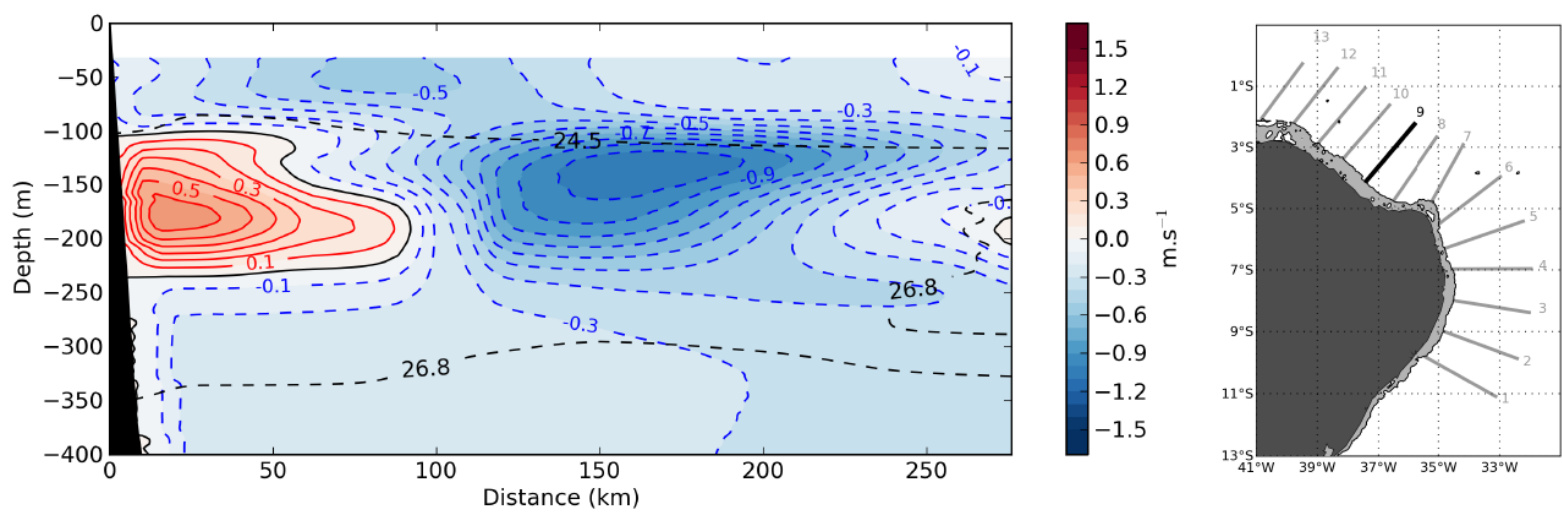

Figure 1.12: Left panel: The ADCP alongshore velocity section within Potiguar bight. The horizontal dashed black lines are the $\sigma_{\theta}=24.5$ and $\sigma_{\theta}=26.8$ isopycnal surface. Eastward velocities are positive. Right panel: The section geographic location. From Krelling (2014).

In terms of dynamical nature, the Potiguar Eddy is a typical mesoscale feature with an elliptical shape. The larger (smaller) axis is about $330 \mathrm{~km}(160 \mathrm{~km})$ wide in ocean with a $140 \mathrm{~km}$ baroclinic deformation radius. Indeed, its Burger number is of order $10^{0}$, which shows that its potential vorticity is not dominated by the relative vorticity. Moreover, Krelling (2014) evaluated its Rossby number as of order $10^{-1}$. This indicates that, in spite of the Potiguar Bight be centered at $4^{\circ} \mathrm{S}$, the eddy mean structure is majorly in geostrophic balance.

\subsection{Motivation}

The equatorial Brazilian margin is seen as a new frontier of mineral resources exploration, such as the Ceará and Barreirinhas oil-gas blocks. Nevertheless its economic relevance and contribution to heat and mass transport from south to north hemisphere, the North Brazil Undercurrent (NBUC) has very few information in terms of its multiple retroflections and recirculations and the accompanying temporal variability. There is no report of the NBC/NBUC system between $0^{\circ}-3^{\circ} \mathrm{S}$.

Moreover, the knowledge about the western boundary current dynamics is crucial for assessing the impact for human activities on the study area, such as oceanic engineering, oil and gas 
exploration infrastructure, environmental monitoring and elaboration of a contingency plan for environmental disasters.

\subsection{Scientific Hypotheses and Questions}

The Barreirinhas Bight, from $0^{\circ}-2^{\circ} \mathrm{S}$, has dimensions and similar bathymetric configuration to those of the Potiguar Bight. The Potiguar Eddy discovery invites to speculate whether similar vortical feature exists in the northern bight Figure 1.13. We also speculate that despite the proximity to the Potiguar Bight, if there are eddies, their dynamics is probably somewhat different. While the southern bight is on the border of the so-called equatorial belt, the northern bight is embedded in it. In the Potiguar Bight, we should expect that equatorial and subtropical dynamics coexist; in the Barreirinhas Bight, the dynamics should thoroughly equatorial, and therefore, ageostrophic.

The description of the NBC/NBUC system within the Barreirinhas Bight limits is restricted to one single synoptic section presented in Figure 1.5. No information about the temporal variability has been reported so far in the literature.

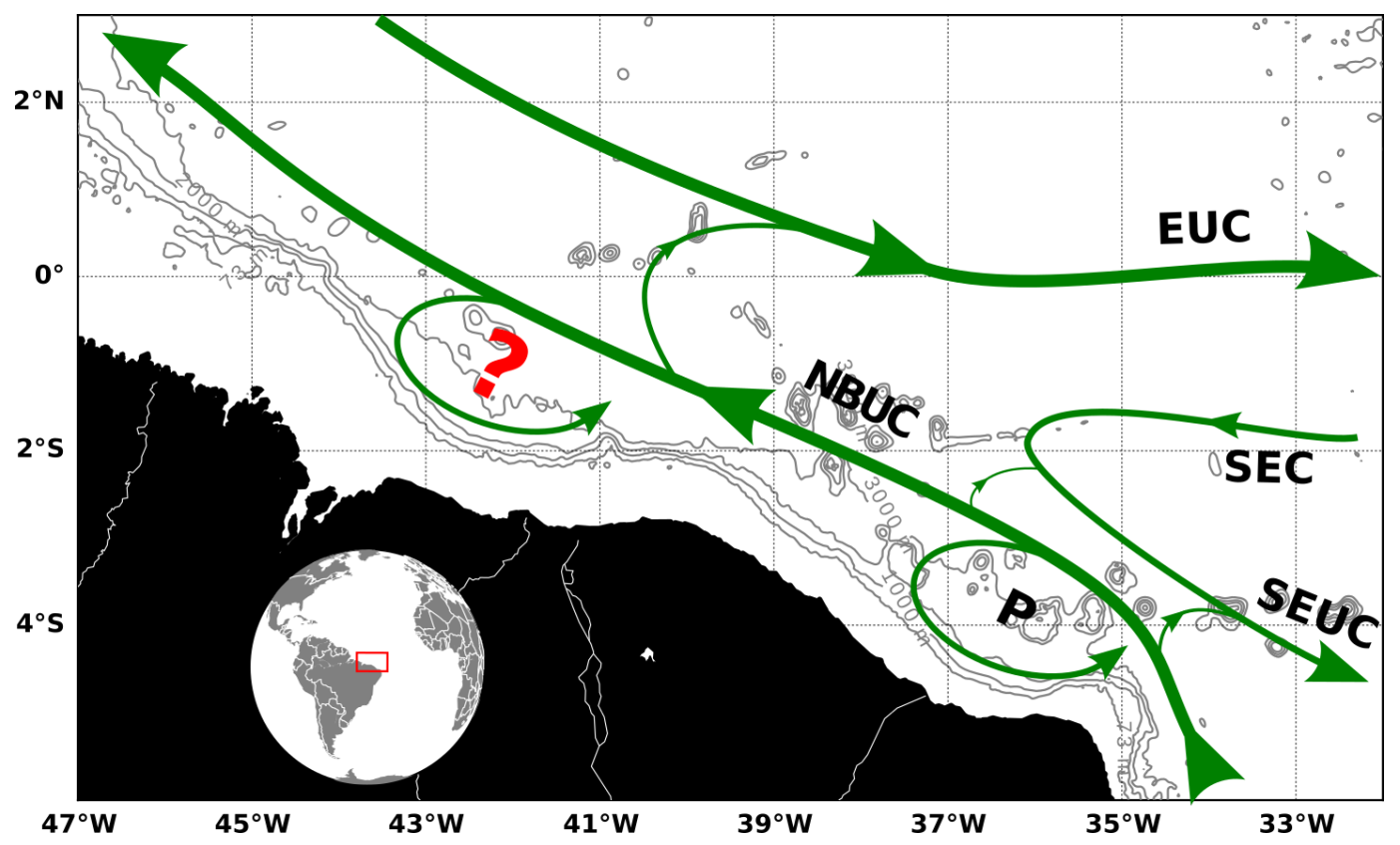

Figure 1.13: The current pattern for South Atlantic Central Water domain in study area. ?: our study area. SEC: South Equatorial Current; NBUC: North Brazil Undercurrent; SEC: South Equatorial Current; SEUC: South Equatorial Undercurrent; P: Potiguar Eddy. Adapted from Schott et al. (1998) and Soutelino et al. (2013).

Based on the previous studies on the Potiguar Bight boundary current activity, we formulate this thesis main hypothesis as being: 


\section{The NBC/NBUC recirculates due to orientation changes of the continental margin within}

Barreirinhas Bight and develops vortical features.

From the main hypothesis, we add two supplementary hypotheses due to the possible bight hydrodynamics. The first secondary hypothesis assumes that the nearequatorial eddy present in the Barreirinhas B is stationary, as the Potiguar Eddy is. The second supplementary hypothesis that its dynamics probably differ greately from the Potiguar Eddy due its latitude. We then formulate the two supplementary hypotheses as:

\section{The Barreirinha Eddy is a quasi-permanent phenomenon.}

\section{The Barreirinha Eddy dynamics is ageostrophic.}

Testing these hypotheses we expect to answer the following a more general question and three specific questions below:

\section{How does the NBC/NBUC vortical activity occur within the Barreirinhas Bight?}

- What are the vertical structure and horizontal dimensions of the features?

- What is the time variability of these features?

- What is the basic dynamics dictating the eddy occurrence?

\subsection{Objectives}

The central goal of this dissertation is to investigate the dynamics of the vortical activity of the NBUC while flowing adjacent to the Barreirinhas Basin. In particular, We intend to elucidate its intra-seasonal variability. To reach this objective we defined the following specific objectives:

- To describe the vortical features associated with the NBUC at intraseasonal time scales within the study area;

- To search for recurrence periods and/or seasonal modulation of such intraseasonal variability; and

- To address the dynamics responsible for the development of the intraseasonal variability. 


\subsection{Summary and Discussion}

North of Cape São Roque $\left(5.5^{\circ} \mathrm{S}\right)$, the Brazilian Northeast Continental Margin is characterized by two twin bights separated by the Acaraú River High. The southern bight, which extends from $3^{\circ} \mathrm{s}$ to $5^{\circ} \mathrm{S}\left(35^{\circ} \mathrm{W}\right.$ to $\left.38^{\circ} \mathrm{W}\right)$, is known as the Potiguar Bight. The northern one extends fro $0^{\circ}$ to $2^{\circ} \mathrm{S}\left(40^{\circ} \mathrm{W}\right.$ to $\left.44^{\circ} \mathrm{W}\right)$, is the Barreirinhas Bight. The western boundary current system flowing adjacent to the continental shelf is the NBC/NBUC system, which transports between 30 and $40 \mathrm{~Sv}$ in this area (Silveira et al., 1994; Stramma et al., 1995; Schott et al., 1998; Goes et al., 2005).

South of Cape São Roque, the NBUC flows attached to the slope and its core is only some 20-30 km distant from the shelf break (Silveira et al., 1994; Goes et al., 2005; Schott et al., 2005). As the coastline and the continental margin change their orientation from north-south to northwest-southeast (about $45^{\circ}$ relative to the north), the NBUC by its inertia flow into deeper water and meanders anticyclonically to reattach to the western boundary. While the meander presents a very weak signature at surface level (if any), it is very evident at the pycnocline level. The formed anticyclonic SACW recirculatio and accommodated in the Potiguar Bight limits was described only recently by Krelling (2014). This author analyzed in situ data from mooring lines and cruises to show that elliptical eddy is a permanent mesoscale feature in geostrophic balance and which present an important 30-day variability. This variability is due to equatorially-trapped Yanai waves, such as those described for the mirror latitude in the southern hemisphere by Schott et al. (1993) and Johns et al. (1998).

As the NBUC reaches the latitude of the Acaraú River Mouth receives important amount of volume from the impinging branches of the SEC, its core becomes shallower Silveira et al. (1994); Schott et al. (1995); Goes et al. (2005). At this inflexion point on the continental margin $\left(3^{\circ} \mathrm{S}, 40^{\circ} \mathrm{W}\right)$, the NBC/NBUC is reattached to the slope with the core distant only $40-50 \mathrm{~km}$ from the shelf break (Goes et al., 2005). As the NBC/NBUC jet passes by the Acaraú River Mouth, it reaches the Barrerinhas Bight off Piauí and Maranhão States. The very few quasi-synotic VMACP sections show a velocity structure which closely resembles that described by Krelling (2014) for the Potiguar Eddy. The motivation of this thesis is to describe the vortical activity of the "Barreirinhas Eddy", to understand its temporal variability and to seek for the very basics of its dynamics.

As we examined the VMADCP section available to us, the naturally first speculation is that the twin bights was present twin stationary mesoscale anticyclones. However, the mere 
computation of the dimensionless quantities such as the aspect ratio, the Rossby number, the Richardson number and the Burger number revealed us a very different dynamic nature. The Barreirinhas Eddy is hydrostatic with an aspect ratio similar to that found by Krelling (2014) for the Potiguar feature. However, both Rossby and Richarson numbers are $\mathrm{O}(1)$. Lévy et al. (2012) and Mahadevan (2016) suggest that features with such order magnitude for the those parameters are ageostrophic, submesoscale motions. Indeed, submesoscale phenomena present typical length scales of about 0.1 to 0.33 of the first deformation radius. The inferred Barreirinhas Eddy radii found are about $35 \mathrm{~km}(86 \mathrm{~km})$ for the near-surface (pycnoclinic) inshore lobe. As the local first baroclinic deformation radius (calculated using an equatorial $\beta$-plane and a local depth $1800 \mathrm{~m}$ ) is $304 \mathrm{~km}$, the ratios are 0.11 and 0.28 . We then state that Barreirinhas Eddy is an equatorial submesoscale anticyclone, as depicted from the ONI cruise transect (Figure 3.2 and Figure 3.3).

The vertical sections of the Barreirinhas Eddy captured by the ONI cruise reveal an interesting characteristic not discussed yet: the profiles in their inshore portions undergo a minimum value at about $120 \mathrm{~m}$ and present two local maxima in vertical, associated with the main TW upper eddy $(\sim 60 \mathrm{~m})$ and SACW mainly, pycnocline eddy $(\sim 150 \mathrm{~m})$. A first possible explanation would be that the inshore lobes mimics the NBC/NBUC vertical structure, which is changing from an undercurrent to a more usual surface current pattern prior to crossing the equator. $\mathrm{A}$ second and more likely explanation is that the eddy is either due to the tilting behave itself as a baroclinic dipole or the velocity pattern depicted in the data actually consist of at least two stacked vortical features. The large Burger number computed for the levels of the two maxima are of $\mathrm{O}\left(10-10^{2}\right)$, as described by Cushman-Roisin and Beckers (2011), indicates that the strong stratification of the study area decouples the density layers and the vortical dynamics is dominated by the relative vorticity.

In order to address whether the Barreirinhas Eddy (or Barreirinhas Eddies, since each layer can be independent in motion of each other) is stationary or not, we analyzed one year of PETROBRAS' BAR1 current meter mooring examining the alongshore (or along-isobath) velocity component. The mean alongshore velocity profile has a character of the NBC vertical structure; no signal of the eddy in the 2007 average profile. Our interpretation is that the Barreirinhas features are not stationary. The EOF calculation revealed us that the dominant patterns of variability are associated with current inversions compatible with the eddy structures which vary importantly in the vertical. The plot of the whole series also allowed us to establish that 
there is an "eddy season" between March and August. Also, a simple statistics on the time series allowed us to show that the mooring registered typically periods of 5-7 days for the current inversions (i.e., they turn eastward instead of the typical westward NBC direction).

In order to expand the analyses spatially and temporally, we use the global HYCOM simulation reanalysis named Experiment 19.1. We confirm the features reproduced in the numerical output with the few observations available and summarized above (years 2001 and 2007). Our output description revealed that the eddies formed are always anticyclonic. They are formed within the bight and propagate westward with different speeds at the different layers. In the simulation the eddy life cycle spanned usually around week with few exceptions, such as the only one we sampled quasi-synoptically in 2001. In this particular case, the eddy propagated slowly and lasted 25 days. The destruction of the eddies usually occur as they try to overcome the geomorphological features in the equatorial limit of the Barreirinhas Bight.

The horizontal distributions of the HYCOM simulation also suggested that the morphometric aspects of the eddies at the near-surface and pycnoclinic level differ considerably. The upper eddy has a very elongated elliptical shape with the cross-shore radius barely surpassing $40 \mathrm{~km}$. The alongshore radius is typically $80 \mathrm{~km}$. The pycnoclinic feature is more circular with a typical radius of $90 \mathrm{~km}$.

We estimated the NBC transport annual cycle (per unit of length) for the 9-year extent of Experiment 19.1 and for the near-surface and the pycnoclinic levels. We found the maximum in May and the minimum in September-October. This NBUC/NBC cycle differ from those evaluated at $11^{\circ} \mathrm{S}$ Schott et al. (2005), therefore near the NBUC origin site, and $7^{\circ} \mathrm{N}$ Johns et al. (1998) for the NBC surface retroflection region. The former authors found a maximum in July and a minimum in October. The latter authors found maximum also in August and the minimum in April, when the NBC does not retroflect.

We speculate that the Barreirinhas eddy season begins when the NBC/NBUC start strengthening in March and ends when the jet weakens in late August. The BAR1 mooring measured 8 (12) events at near surface (the pycnocline).

"Eddy seasons" in near-equatorial phenomena also occur in the North Atlantic despite being a result of fairly different dynamics. A well studied example is the NBC eddy-shedding which occurs typically between $4^{\circ} \mathrm{N}$ and $6^{\circ} \mathrm{N}$ and between late June and February (no shedding during March-May). (Johns et al., 1990; Fratantoni et al., 1995; Didden and Schott, 1993; Johns et al., 1998; Silveira et al., 2000; Wilson et al., 2002). This eddy shedding is associated with the NBC 
retroflection in its process of closing the equatorial gyre and separating from the continental margin. Large anticyclones (with radius about 180-250 km) are shed from a necking off process of the current. As the first baroclinic radius is $200 \mathrm{~km}$, the dynamical process is typically mesoscale. After being shed, they propagate bordering the shelf break toward the Caribbean. The shedding is modulated by 50-day Rossby waves and 30-day Yanai waves, the latter being the symmetric northern part of the meridional mode which also affects the Potiguar Eddy at $4^{\circ} \mathrm{S}$ (Johns et al., 1998; Krelling, 2014).

Other interesting near-equatorial mesoscale eddies are those observed in the eastern Pacific linked to the retroflections of the western boundary Mindanao Current $\left(8^{\circ} \mathrm{N}\right)$ and the New Guinea Coastal Current $\left(4^{\circ} \mathrm{N}\right)$, which converge to delimit the border between the tropical and equatorial gyres and feed the Pacific Equatorial Countercurrent (Arruda and Nof, 2003; Kashino et al., 2013). In both currents, quasi-stationary separation eddies are present: the cyclonic Mindanao and the anticyclonic Halmahera Eddies. Both eddies are surface-intensified, however the Mindanao Eddy faces important modulation probably by instability-generated waves, similarly to what is observed in the NBC retroflection at the same latitude range of the Atlantic Ocean. Hence, these western Pacific phenomena is not directly comparable to what we observe within Barreirinhas Bight.

The Barreirinhas Eddy formation occur as the NBC flow along the Brazilian continental slope. The flow configuration here (so is the Potiguar Eddy) are not associated with a separating boundary current. Therefore, the phenomenon which seems closer to the Barreirinhas eddy formation is the one in the Gulf of Guinea described by Djakouré et al. (2014). These authors have reported that the Canary Current and the North Equatorial Countercurrent merge to form the Guinea Current. This current flows by Cape Palmas and Cape Three Points. As the current surpasses the geomorphological features, it forms propagating cyclones. The authors informed that the average cyclone radius is $60 \mathrm{~km}$ (compared to a $130 \mathrm{~km}$ local baroclinic deformation radius), the Rossby Number is 0.6 and the Burger number, 3. The Guinea Current Eddies do appear as a mirror image of what is observed in Barreirinhas Bight and thus, the Barreirinhas Eddies dimensionless parameters are right to a anticyclonic-eddy-shedding regime described by Boyer and Tao (1987). The Guinea cyclones shedding phenomenon present important ageostrophic and the $\mathrm{O}(1)$ Burger number suggests that relative and stretching vorticities compete in the vorticity balance. The ratio between the eddy and the deformation radii is about 0.5. So, the Guinea Current eddies present important and distinct characteristics relative to 
the Barreirinhas'. Nevertheless, the role of capes and/or drastic changes in continental margin orientation leads to the meander formation probably in an analogous fashion in both sites.

The Guinea Current produces about 3-4 cyclones per year with a life span of about 50-60 days. They are only formed during the boreal summer (the Gulf of Guinea upwelling season), according to Djakouré et al. (2014). The NBC/NBUC jet generates about 10 events per year with a short life span of 5-7 days concentrated in six months.

\subsection{Conclusions}

In this section, we present the answers to the four scientific questions and which represent the conclusions drew from the analysis and interpretation of observations and confirmed numerical model outputs.

\section{How does the NBC/NBUC vortical activity occur within the Barreirinhas Bight?}

As anticyclonic westward propagating eddies with seasonal occurrence.

\section{What are the vertical structure and horizontal dimensions of the features?}

There is two type of eddies, the near-surface (in TW domain) and the pycnoclinic (in SACW domain) eddy. The near-surface (pycnoclinic) eddy has $100 \mathrm{~m}(150 \mathrm{~m})$ of vertical extent and a cross-shore radius of about $35 \mathrm{~km}(80 \mathrm{~km})$. The shallower one is isotropic with a alongshore radius of $80 \mathrm{~km}$.

\section{What is the time variability of these features?}

Both occur mainly from March to August typically as 7-day recurrent events with higher number of events in May.

\section{What is the basic dynamics dictating the eddy occurrence?}

They are hydrostatic, submesoscale-like features dominated by relative vorticity.

As for the test of the main thesis hypothesis, we confirm that the NBC/NBUC jet recirculates and shed eddies within Barreirinhas Bight. On other hand we deny the first secondary hypothesis becauses the eddies are not stationary. They propagate westward and are destroyed while leaving the equatorial border of the bight. We confirm the second secondary hypothesis since the Barrerinhas eddies are submesoscale features with vortical dynamics governed by relative vorticity unlike the Krelling (2014) Potiguar eddy. The latter eddy is a mesoscale dominantly 
geostrophic feature.

\subsection{Future Work}

In this thesis, we had the opportunity to describe and characterize a new phenomenon occurring on the Brazilian continental margin: the Barreirinhas submesoscale anticyclonic formation. We are able to gather and interpret the few observations available and expand the our investigation temporally and spatially via confirmation of a global model experiment by the HYCOM consortium to expand the our investigation temporally and spatially. However, we believe additional dynamical studies should conducted for a better understanding and eventually prediction of the eddy events. This thesis only grasped the very basic fundamentals of the dynamics governing the NBC-NBUC eddy shedding. Certainly, a process numerical study employing a Primitive Equation reduced gravity model and idealized topography, similar to the work Boyer and Tao (1987) done with a rotating tank. 


\section{Bibliography}

Arruda, W. Z., and D. Nof (2003), The mindanao and halmahera eddies-twin eddies induced by nonlinearities, Journal of Physical Oceanography, 33(12), 2815-2830.

Bleck, R., and D. B. Boudra (1981), Initial testing of a numerical ocean circulation model using a hybrid (quasi-isopycnic) vertical coordinate, Journal of Physical Oceanography, 11(6), $755-770$.

Boebel, O., R. Davis, M. Ollitrault, R. Peterson, P. Richardson, C. Schmid, and W. Zenk (1999), The intermediate depth circulation of the western south atlantic, Geophysical Research Letters, 26(21), 3329-3332.

Boyer, D. L., and L. Tao (1987), On the motion of linearly stratified rotating fluids past capes, Journal of Fluid Mechanics, 180, 429-449.

Bruce, J., J. Kerling, and W. Beatty (1985), On the north brazilian eddy field, Progress in oceanography, 14, 57-63.

Cochrane, J. D., F. J. Kelly Jr, and C. R. Olling (1979), Subthermocline countercurrents in the western equatorial atlantic ocean, Journal of Physical Oceanography, 9(4), 724-738.

Cushman-Roisin, B., and J. Beckers (2011), Introduction to geophysical fluid dynamics: Physical and numerical aspects, Academic Press.

Da Silveira, I., L. Calado, B. Castro, M. Cirano, J. Lima, and A. d. S. Mascarenhas (2004), On the baroclinic structure of the brazil current-intermediate western boundary current system at 22-23 s, Geophysical Research Letters, 31(14).

Didden, N., and F. Schott (1993), Eddies in the north brazil current retroflection region observed by geosat altimetry, Journal of Geophysical Research: Oceans, 98(C11), 20,121-20,131. 
Djakouré, S., P. Penven, B. Bourlès, J. Veitch, and V. Koné (2014), Coastally trapped eddies in the north of the gulf of guinea, Journal of Geophysical Research: Oceans, 119(10), 68056819.

Firing, E., J. Ranada, and P. Caldwell (1995), Processing ADCP data with the CODAS software system version 3.1, Tech. rep., Joint Inst. for Mar. and Atmos. Res./NODC, University of Hawaii at Manoa, Honolulu.

Fratantoni, D. M., W. E. Johns, and T. L. Townsend (1995), Rings of the north brazil current: Their structure and behavior inferred from observations and a numerical simulation, Journal of Geophysical Research: Oceans, 100(C6), 10,633-10,654.

Goes, M., R. Molinari, I. da Silveira, and I. Wainer (2005), Retroflections of the north brazil current during february 2002, Deep Sea Research Part I: Oceanographic Research Papers, 52(4), 647-667.

HYCOM (2010), Global 1/12 simulation.

Johns, W., T. Lee, R. Beardsley, J. Candela, R. Limeburner, and B. Castro (1998), Annual cycle and variability of the North Brazil Current, Journal of Physical Oceanography, 28(1), $103-128$.

Johns, W. E., T. N. Lee, F. A. Schott, R. J. Zantopp, and R. H. Evans (1990), The north brazil current retroflection: Seasonal structure and eddy variability, Journal of Geophysical Research: Oceans, 95(C12), 22,103-22,120.

Kashino, Y., A. Atmadipoera, and Y. Kuroda (2013), Observed features of the halmahera and mindanao eddies, Journal of Geophysical Research: Oceans, 118(12), 6543-6560.

Krelling, A. P. (2014), The potiguar eddy: a subsurface anticyclone associated with the north brazil undercurrent at $4^{\circ} \mathrm{s}$, Phd, Instituto Oceanográfico, USP e Massachusetts University, UMASS, São Paulo.

Lévy, M., R. Ferrari, P. J. Franks, A. P. Martin, and P. Rivière (2012), Bringing physics to life at the submesoscale, Geophysical Research Letters, 39(14).

Mahadevan, A. (2016), The impact of submesoscale physics on primary productivity of plankton, Annual review of marine science, 8, 161-184. 
Marin, F. d. O. (2009), A subcorrente norte do brasil ao largo da costa do nordeste, Mestrado, IO, Instituto Oceanográfico, USP, São Paulo.

Mohriak, W. U. (2003), Bacias sedimentares da margem continental brasileira, in Geologia, Tectônica e Recursos Minerais do Brasil, edited by L. A. Bizzi, C. Schobbenhaus, R. M. Vidotti, and J. H. Gonçalves, chap. 3, CPRM.

Oreskes, N., K. Shrader-Frechette, K. Belitz, et al. (1994), Verification, validation, and confirmation of numerical models in the earth sciences, Science, 263(5147), 641-646.

Philander, S., J. Holton, and R. Dmowska (1989), El Nino, La Nina, and the Southern Oscillation, International Geophysics, Elsevier Science.

Preisendorfer, R., and C. Mobley (1988), Principal Component Analysis in Meteorology and Oceanography, Developments in atmospheric science, Elsevier.

Richardson, P., and G. Reverdin (1987), Seasonal cycle of velocity in the atlantic north equatorial countercurrent as measured by surface drifters, current meters, and ship drifts, Journal of Geophysical Research: Oceans, 92(C4), 3691-3708.

Schott, F., J. Fischer, J. Reppin, and U. Send (1993), On mean and seasonal currents and transports at the western boundary of the equatorial atlantic, Journal of Geophysical Research: Oceans, 98(C8), 14,353-14,368.

Schott, F., J. Fischer, and L. Stramma (1998), Transports and pathways of the upper-layer circulation in the western tropical Atlantic, JOURNAL OF PHYSICAL OCEANOGRAPHY, 28(10), 1904-1928.

Schott, F., M. Dengler, R. Zantopp, L. Stramma, J. Fischer, and P. Brandt (2005), The shallow and deep western boundary circulation of the South Atlantic at 5 degrees-11 degrees $\mathrm{S}$, JOURNAL OF PHYSICAL OCEANOGRAPHY, 35(11), 2031-2053.

Schott, F. A., L. Stramma, and J. Fischer (1995), The warm water inflow into the western tropical atlantic boundary regime, spring 1994, Journal of Geophysical Research: Oceans, 100(C12), 24,745-24,760.

Silveira, I. C. A., L. B. Miranda, and W. S. Brown (1994), On the origins of the north brazil current, Journal of Geophysical Research: Oceans, 99(C11), 22,501-22,512. 
Silveira, I. C. d., W. S. Brown, and G. R. Flieri (2000), Dynamics of the north brazil current retroflection region from the western tropical atlantic experiment observations (paper 2000jc900129), Journal of Geophysical Research-Part C-Oceans, 105(12), 28,559-28,584.

Soutelino, R., A. Gangopadhyay, and I. da Silveira (2013), The roles of vertical shear and topography on the eddy formation near the site of origin of the brazil current, Continental Shelf Research, 70, 46 - 60, oceanography, ecology and management of Abrolhos Bank.

Stramma, L., J. Fischer, and J. Reppin (1995), The north brazil undercurrent, Deep Sea Research Part I: Oceanographic Research Papers, 42(5), 773 - 795.

Thomson, R., W. Emery, W. Emery, and R. Thomson (2001), Data Analysis Methods in Physical Oceanography: Second and Revised Edition, Elsevier Science.

Veleda, D., M. Araujo, R. Zantopp, and R. Montagne (2012), Intraseasonal variability of the north brazil undercurrent forced by remote winds, Journal of Geophysical Research: Oceans, 117(C11).

Wilson, W. D., W. E. Johns, and S. L. Garzoli (2002), Velocity structure of north brazil current rings, Geophysical Research Letters, 29(8). 